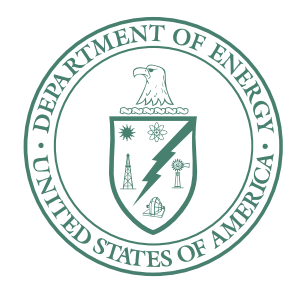

U.S. Department of Energy

Idaho Operations Office

\title{
Engineering Evaluation/ Cost Analysis (EE/CA) for Decommissioning of TAN-607 Hot Shop Area
}

January 2007 
DOE/ID-11302

Revision 0

Project No. 22801

\section{Engineering Evaluation/ \\ Cost Analysis (EE/CA) for Decommissioning of \\ TAN-607 Hot Shop Area}

January 2007

Prepared for the 



\section{SUMMARY}

Test Area North (TAN) -607, the Technical Support Facility, is located at the north end of the Idaho National Laboratory (INL) Site. U.S. Department of Energy Idaho Operations Office (DOE-ID) is proposing to decommission the northern section of the TAN-607 facility, hereinafter referred to as TAN-607 Hot Shop Area, under a Comprehensive Environmental Response, Compensation, and Liability Act (CERCLA) non-time-critical removal action (NTCRA).

Despite significant efforts by the United States (U.S.) Department of Energy (DOE) to secure new business, no future mission has been identified for the TAN-607 Hot Shop Area. Its disposition has been agreed to by the Idaho State Historical Preservation Office documented in the Memorandum of Agreement signed October 2005 and it is therefore considered a surplus facility. A key element in DOE's strategy for surplus facilities is decommissioning to the maximum extent possible to ensure risk and building footprint reduction and thereby eliminating operations and maintenance cost. In addition, the DOE's 2006 Strategic Plan is "complete cleanup of the contaminated nuclear weapons manufacturing and testing sites across the United States. DOE is responsible for the risk reduction and cleanup of the environmental legacy of the Nation's nuclear weapons program, one of the largest, most diverse, and technically complex environmental programs in the world. The Department will successfully achieve this strategic goal by ensuring the safety of the DOE employees and U.S. citizens, acquiring the best resources to complete the complex tasks, and managing projects throughout the United States in the most efficient and effective manner."

TAN-607 is designated as a historical Signature Property by DOE Headquarters Advisory Council on Historic Preservation and, as such, public participation is required to determine the final disposition of the facility. The decommissioning action will place the TAN-607 Hot Shop Area in a final configuration that will be protective of human health and the environment. Decommissioning the TAN-607 Hot Shop Area is consistent with the joint DOE and U.S. Environmental Protection Agency (EPA) Policy on Decommissioning of Department of Energy Facilities Under the Comprehensive Environmental Response, Compensation and Liability Act, which establishes the CERCLA NTCRA process as the preferred approach for decommissioning surplus DOE facilities. Under this policy, a NTCRA may be taken when DOE determines that the action will prevent, minimize, stabilize, or eliminate a risk to human health and/or the environment. When DOE determines that a CERCLA NTCRA is necessary, DOE is authorized to evaluate, select, and implement the removal action that DOE determines is most appropriate to address the potential risk posed by the release or threat of release. This action is taken in accordance with applicable authorities and in conjunction with EPA and the State of Idaho pursuant to Section 5.3 of the Federal Facility Agreement and Consent Order.

In keeping with the joint policy, this engineering evaluation/cost analysis (EE/CA) was developed in accordance with CERCLA as amended by the "Superfund Amendments and Reauthorization Act of 1986" and in accordance with the "National Oil and Hazardous Substances Pollution Contingency Plan." This EE/CA is consistent with the remedial action objectives (RAOs) of the Final 
Record of Decision, Test Area North, Operable Unit 1-10 and supports the overall remediation goals established through the Federal Facility Agreement and Consent Order for Waste Area Group 1. Waste Area Group 1 is located at TAN.

This EE/CA documents and evaluates three alternatives for the decommissioning of TAN-607 Hot Shop Area. The three alternatives are:

1 - No Action Alternative: The No Action alternative is a hypothetical and conservative, "baseline" established for comparison reasons. The primary assumption is that the sum of identified radiological contamination, if not properly contained or controlled, may be released to the environment causing a potential risk to receptors (current and future workers, hypothetical future residents, and the environment). This assumption is for comparative purposes only and does not reflect the DOE mandate to monitor, maintain, and mitigate potential or actual release from any facility or site to ensure protection to the public and the environment.

2 - Cold, Dark, and Dry with Continued Surveillance and Monitoring: Under this alternative, the facility will be placed in a cold, dark, and dry condition. Utilities will be disconnected and remaining liquids will be removed prior to placing the building into long-term surveillance and monitoring. Long-term surveillance and monitoring would continue until the building is finally decommissioned in 2095 .

\section{3 - Demolition, Removal, and Disposal of Building and Building Contents to} Meet the Remedial Action Objectives: This alternative consists of demolishing the TAN-607 aboveground structures and components, removing belowground noninert components (e.g., wood products), and removing the radiologically contaminated debris that does not meet RAOs, as defined in the Record of Decision Amendment for the $V$-Tanks (TSF-09 and TSF-18) and Explanation of Significant Differences for the PM-2A Tanks (TSF-26) and TSF-06, Area 10, at Test Area North, Operable Unit 1-10. Radiologically contaminated debris that does meet the RAOs will be left in the excavation created from demolition of TAN-607 and the adjacent void remaining after completion of the V-Tanks soil removal project. Radiologically contaminated debris that does not meet the RAOs will be disposed of in the Idaho CERCLA Disposal Facility (ICDF) subject to meeting the Waste Acceptance Criteria (WAC). Nonradiologically contaminated and nonhazardous waste will be disposed of at the TAN Demolition Landfill subject to meeting the WAC. If waste does not meet the TAN Demolition Landfill or ICDF WAC, a suitable off-Site disposal location will be determined (e.g., EnergySolutions). Upon completion of demolition, the remaining void will be backfilled with solid inert material, graded to meet the natural contour of the area and reseeded.

Alternative 3 is the recommended alternative. This alternative meets the proposed RAOs and also supports the DOE-ID 2006 Strategic Plan to ensure protection of human health and the environment while achieving an end state that provides the lowest risk and cost with the fewest post-closure activities. It also eliminates unnecessary infrastructure and overhead costs and reduces the Environmental Management footprint liability.

This EE/CA will become part of the INL Administrative Record. It will be made available for public comment. The INL Administrative Record is on the 
Internet at http://ar.inel.gov/ and is available to the public at the following locations:

$\begin{array}{ll}\text { Albertsons Library } & \text { INL Technical Library } \\ \text { Boise State University } & \text { DOE Public Reading Room } \\ 1910 \text { University Drive } & \text { 1776 Science Center Drive } \\ \text { Boise, ID } 83725 & \text { Idaho Falls, ID } 83415 \\ \text { (208) } 426-1625 & \text { (208) 526-1185 }\end{array}$





\section{CONTENTS}

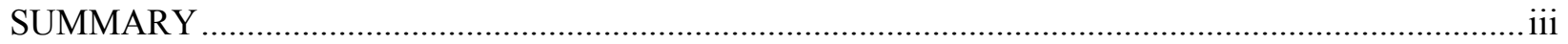

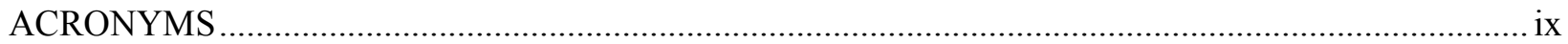

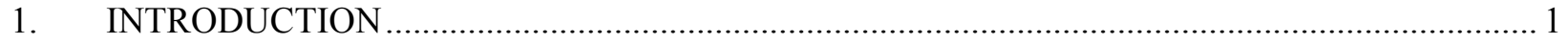

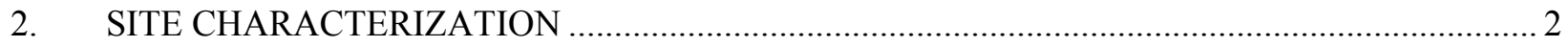

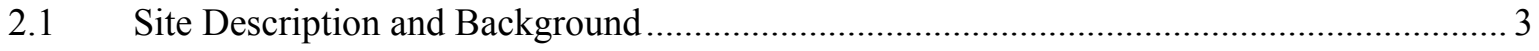

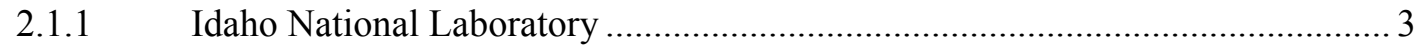

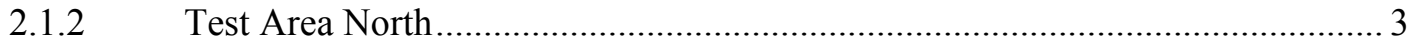

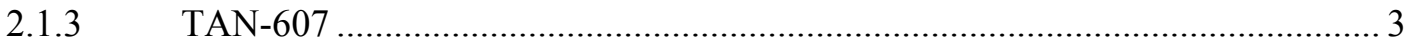

2.2 Previous Closure/Cleanup Activities at TAN ............................................................. 7

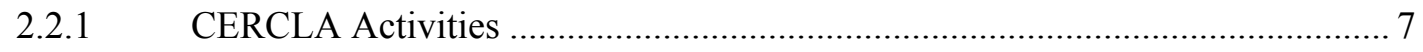

2.2.2 Voluntary Consent Order HWMA/RCRA Closure Activities ............................ 8

2.3 Cleanup Activities Currently Ongoing at TAN-607 Hot Shop Area ................................ 8

2.4 Extent of Contamination and Remaining Inventories ............................................... 8

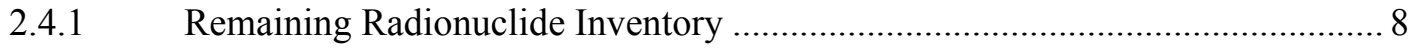

2.4.2 Remaining Nonradionuclide Inventory ….................................................... 9

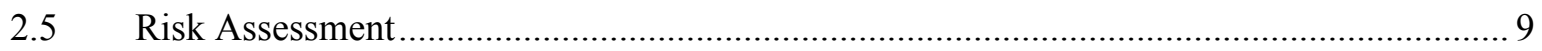

2.5.1 Risk Assessment from Radiological Source Term...................................... 10

3. IDENTIFICATION OF REMOVAL OBJECTIVES AND SCOPE ......................................... 14

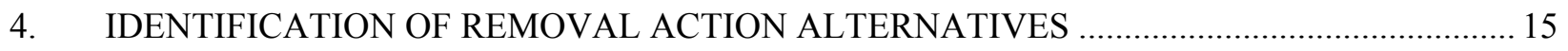

4.1 Alternative 1 - No Action Alternative …...................................................................... 15

4.2 Alternative 2 - Cold, Dark, and Dry with Continued Surveillance and Monitoring ........... 15

4.3 Alternative 3 - Demolition, Removal, and Disposal of Building and Building Contents to Meet the Remedial Action Objectives......................................................................... 15

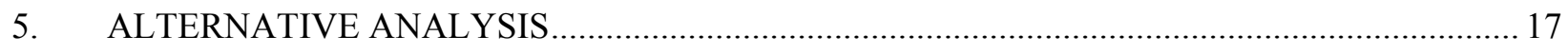

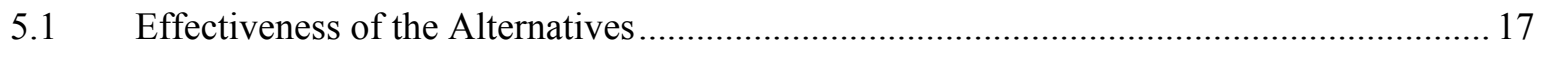

5.1.1 Protectiveness of Public Health and the Environment ....................................... 17

5.1.2 Ability to Achieve Non-Time-Critical Removal Action Objectives.................. 19 


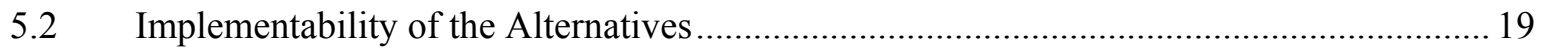

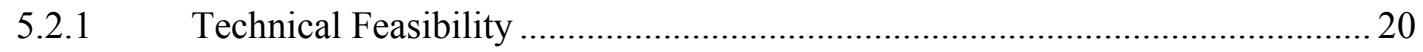

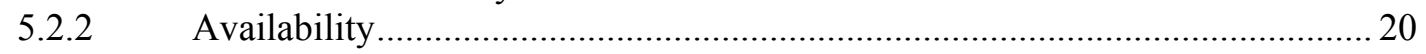

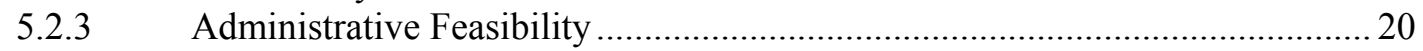

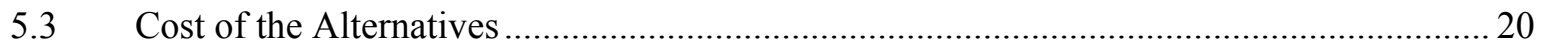

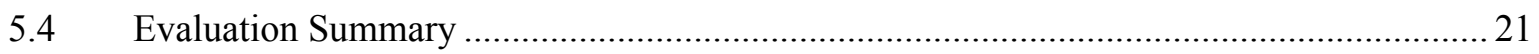

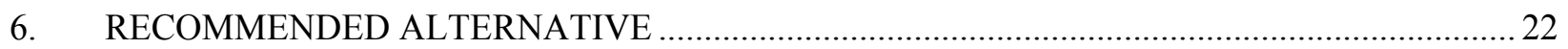

6.1 Compliance with Environmental Regulations, Including Those That Are Applicable or

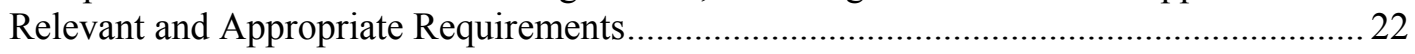

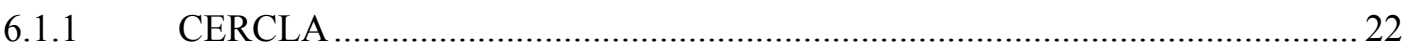

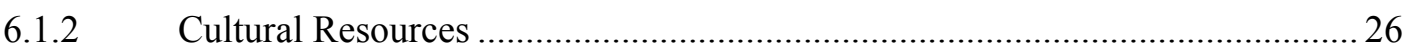

6.2 Compliance with Non-INL Disposal Facility Waste Acceptance Criteria ........................ 27

6.3 TAN Demolition Landfill Waste Acceptance Criteria ...................................................... 27

6.4 Idaho CERCLA Disposal Facility Waste Acceptance Criteria .......................................2 27

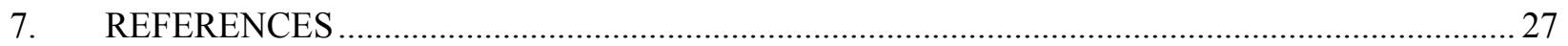

\section{FIGURES}

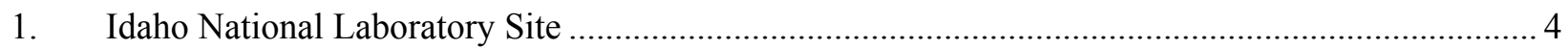

2. TAN-607, Technical Support Facility (looking northeast)....................................................... 5

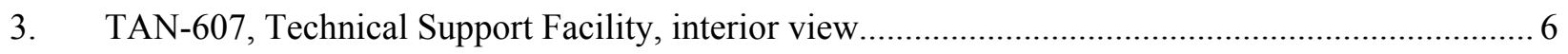

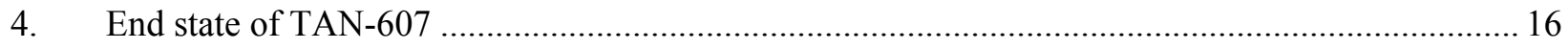

\section{TABLES}

1. Summary of radiological activity in TAN-607 (in curies) in 2006 and decayed to 2095 ................ 9

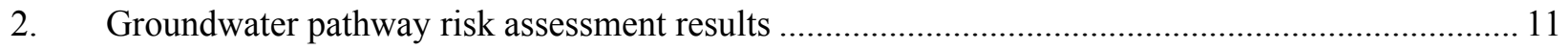

3. Radiological estimated risk results for residential scenario ...................................................... 13

4. Comparison of calculated soil concentrations to EBSL ............................................................ 14

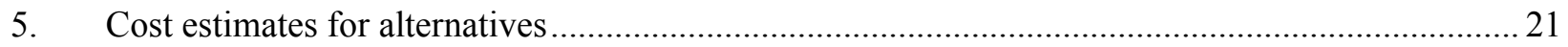

6. Summary of ARARs for the TAN-607 Hot Shop Area, non-time-critical removal action ..............23 


\section{ACRONYMS}

ACHP Advisory Council on Historic Preservation

ANPP Aircraft Nuclear Propulsion Program

ARAR applicable or relevant and appropriate requirement

CERCLA Comprehensive Environmental Response, Compensation, and Liability Act

CFA Central Facilities Area

CFR Code of Federal Regulations

DEQ Department of Environmental Quality (Idaho)

DOE Department of Energy

DOE-ID Department of Energy Idaho Operations Office

EBSL ecologically based screening level

EDF Engineering Design File

$\mathrm{EE} / \mathrm{CA} \quad$ engineering evaluation/cost analysis

EPA Environmental Protection Agency

FFA/CO Federal Facility Agreement and Consent Order

HWMA Hazardous Waste Management Act

ICDF Idaho CERCLA Disposal Facility

ICP Idaho Cleanup Project

IDAPA Idaho Administrative Procedures Act

IETF Initial Engine Test Facility

INL Idaho National Laboratory

LOFT Loss-of-Fluid Test

MOA Memorandum of Agreement

NTCRA non-time-critical removal action

OU operable unit

PCB polychlorinated biphenyl 


$\begin{array}{ll}\text { RACM } & \text { regulated asbestos-containing material } \\ \text { RAO } & \text { remedial (removal) action objective } \\ \text { RCRA } & \text { Resource Conservation Recovery Act } \\ \text { ROD } & \text { Record of Decision } \\ \text { SES } & \text { Special Equipment Service } \\ \text { SHPO } & \text { State Historic Preservation Office (Idaho) } \\ \text { SMC } & \text { Specific Manufacturing Capability } \\ \text { TAN } & \text { Test Area North } \\ \text { TSCA } & \text { Toxic Substances Control Act } \\ \text { TSF } & \text { Technical Support Facility } \\ \text { USC } & \text { United States Code } \\ \text { VCO } & \text { Voluntary Consent Order } \\ \text { WAC } & \text { Waste Acceptance Criteria } \\ \text { WRRTF } & \text { Water Reactor Research Test Facility }\end{array}$




\section{Engineering Evaluation/Cost Analysis (EE/CA) for Decommissioning of TAN-607 Hot Shop Area}

\section{INTRODUCTION}

This engineering evaluation/cost analysis (EE/CA) has been developed in accordance with the Comprehensive Environmental Response, Compensation, and Liability Act of 1980 (CERCLA) (42 USC $\S 9601$ et seq.) as amended by the Superfund Amendments and Reauthorization Act of 1986 (Public Law 99-499) and in accordance with the National Oil and Hazardous Substances Pollution Contingency Plan (40 Code of Federal Regulations [CFR] 300). The U.S. Department of Energy Idaho Operations Office (DOE-ID) is proposing to decommission this northern portion of TAN-607, referred to as the Test Area North (TAN) -607 Hot Shop Area, under a CERCLA non-time-critical removal action (NTCRA). Under the U.S. Department of Energy (DOE) and U.S. Environmental Protection Agency (EPA) Policy on Decommissioning of Department of Energy Facilities Under the Comprehensive Environmental Response, Compensation and Liability Act (DOE and EPA 1995), a NTCRA may be taken when DOE determines that the action will prevent, minimize, stabilize, or eliminate a risk to health and/or the environment. When DOE determines that a NTCRA is necessary, DOE is authorized to evaluate, select, and implement the removal action that DOE determines is most appropriate to address potential risks posed by the release or threat of release. The NTCRA is taken in accordance with applicable authorities and in conjunction with EPA and the State of Idaho pursuant to Section 5.3 of the Federal Facility Agreement and Consent Order (FFA/CO). This EE/CA identifies the objectives of the NTCRA and analyzes the effectiveness, implementability, and cost of decommissioning alternatives that satisfy these objectives.

TAN-607, the Technical Support Facility (TSF), is located at the north end of the Idaho National Laboratory (INL) Site in an area known as TAN. This area was established to support nuclear-powered aircraft research. Upon termination of this research, TAN facilities were converted to support a variety of other DOE-ID-sponsored projects related to reactor research. TAN-607 was constructed from 1955 to 1957 and was equipped with office and administration areas, manufacturing and maintenance areas, a storage pool and storage pool vestibule, shielded work areas, overhead cranes, decontamination areas, and high bays. The southern portion of TAN-607 contained the manufacturing and maintenance areas, administration areas, decontamination areas, and high bays and was referred to as TAN-607A. The scope of this proposed removal action is limited to the TAN-607 Hot Shop Area, because TAN-607A is currently being decommissioned. Decommissioning of TAN-607A began in September 2006 and was addressed in Engineering Evaluation/Cost Analysis (EE/CA) Decommissioning of TAN-607A (ICP 2006).

Currently, deactivation actions are being performed. The actions include asbestos abatement, utility isolation, decontamination, removing the radiologically contaminated ventilation system, and sampling and removing the radiologically contaminated filter banks. All potential Hazardous Waste Management Act (HWMA)/Resource Conservation and Recovery Act (RCRA) and Toxic Substances Control Act (TSCA) constituents (e.g., polychlorinated biphenyl [PCB] light ballasts, lead, mercury switches) are also being removed.

DOE will issue an Action Memorandum to document the alternative selection. Decommissioning activities will commence in accordance with the approach specified in the alternative selected in the Action Memorandum. The selected alternative will ensure that the TAN-607 Hot Shop Area will be placed in a configuration that is protective of human health and the environment. The removal action will be consistent with the joint DOE and EPA Policy on Decommissioning of Department of Energy 
Facilities Under the Comprehensive Environmental Response, Compensation and Liability Act (DOE and EPA 1995), which supports use of the CERCLA NTCRA process as an approach for decommissioning.

DOE-ID has developed three alternatives for the decommissioning of the TAN-607 Hot Shop Area. The alternatives are summarized as follows and discussed in detail in Section 4:

- $\quad$ Alternative 1 - No Action Alternative: The No Action alternative is a hypothetical and conservative, "baseline" established for comparison reasons. The primary assumption is that the sum of identified radiological contamination, if not properly contained or controlled, may be released to the environment causing a potential risk to receptors (current and future workers, hypothetical future residents, and the environment). This assumption is for comparative purposes only and does not reflect the DOE mandate to monitor, maintain, and mitigate potential or actual release from any facility or site to ensure protection to the public and the environment.

- $\quad$ Alternative 2 - Cold, Dark, and Dry with Continued Surveillance and Monitoring: Under this alternative, the facility will be placed in a cold, dark and dry condition. Utilities will be disconnected and remaining liquids will be removed prior to placing the building into long-term surveillance and monitoring. Long-term surveillance and monitoring would continue until the building is finally decommissioned in 2095. This period is based on the assumption in the TAN Operable Unit 1-10 Record of Decision (ROD) that DOE will retain institutional control at TAN until 2095.

- $\quad$ Alternate 3 - Demolition, Removal, and Disposal of Building and Building Contents to Meet the Remedial Action Objectives: This alternative consists of demolishing the TAN-607 aboveground structures and components, removing belowground noninert components (e.g., wood products), and removing the radiologically contaminated debris that does not meet remedial action objectives (RAOs), as defined in the Record of Decision Amendment for the V-Tanks (TSF-09 and TSF-18) and Explanation of Significant Differences for the PM-2A Tanks (TSF-26) and TSF-06, Area 10, at Test Area North, Operable Unit 1-10 (DOE-ID 2004). Radiologically contaminated debris that does meet the RAOs will be left in the excavation created from demolition of TAN-607 and the adjacent void remaining after completion of the V-Tanks soil removal project.

Radiologically contaminated debris that does not meet the RAOs will be disposed of in the Idaho CERCLA Disposal Facility (ICDF) subject to meeting the Waste Acceptance Criteria (WAC). Nonradiologically contaminated and nonhazardous waste will be disposed of at the TAN Demolition Landfill subject to meeting the WAC. If waste does not meet the TAN Demolition Landfill or ICDF WAC, a suitable off-Site disposal location will be determined

(e.g., EnergySolutions). Upon completion of demolition, the remaining void will be backfilled with solid inert material, graded to meet the natural contour of the area and reseeded.

\section{SITE CHARACTERIZATION}

This section briefly summarizes available information describing the TAN-607 Hot Shop Area. In particular, this section addresses the site description and background of INL and TAN, previous and ongoing closure and cleanup actions at the TAN-607 Hot Shop Area, deactivation activities at the TAN-607 Hot Shop Area that are currently underway, a summary of the radiological and nonradiological characterization of the TAN-607 Hot Shop Area, and the streamlined risk assessment associated with the alternatives. 


\subsection{Site Description and Background}

\subsubsection{Idaho National Laboratory}

The INL Site is an $890-\mathrm{mi}^{2}$ DOE facility located on the Snake River Plain in southeastern Idaho. DOE-ID controls the land within the INL Site, and public access is restricted to public highways, DOE-ID-sponsored tours, special-use permits, and the Experimental Breeder Reactor-I National Historic Landmark. DOE-ID permits Shoshone-Bannock tribal members access to specific areas on the INL Site for cultural and religious purposes.

The INL consists of several facility areas situated on an expanse of otherwise undeveloped, cool-desert terrain. Buildings and structures at the INL are clustered within those facility areas, which are typically less than a square mile in size and separated from each other by miles of primarily undeveloped land. TAN is located at the north end of the INL about 27 miles northeast of the Central Facilities Area (CFA) (See Figure 1).

Population centers in the region include large towns in Idaho ( $>10,000$ residents) such as Idaho Falls, Pocatello, Rexburg, and Blackfoot, which are located approximately 50 miles to the east and south, and several smaller towns $(<10,000)$ located around the INL such as Arco, Howe, and Atomic City.

\subsubsection{Test Area North}

TAN is the most northerly group of facilities on the INL Site. The facilities were largely constructed between 1954 and 1961 to support the Aircraft Nuclear Propulsion Program (ANPP). Upon termination of this research, TAN structures were converted to support a variety of DOE-ID research projects. TAN encompassed several facilities including the TSF, the Initial Engine Test Facility (IETF), Lost-of-Fluid Test (LOFT) facility, Specific Manufacturing Capability (SMC) facility, and the Water Reactor Research Test Facility (WRRTF). The IETF, WRRTF, and LOFT have been completely demolished. SMC supports activities for the Department of the Army and is currently operational. Several decommissioning activities are ongoing at the TSF.

\subsubsection{TAN-607}

TAN-607, also known as TSF, was constructed between 1955 and 1957. TAN-607 is the original portion of the TSF and includes the hot shop/hot shop extension/Special Equipment Service (SES) room, storage pool and vestibule, hot cell, warm shop, and other support areas, including administrative, storage, and mechanical. See Figure 2 for an exterior view of TAN-607. The plan view of the portion of TAN-607 that is being addressed under this EE/CA is shown in Figure 3 as the unshaded area.

The hot shop was originally constructed in 1955 in support of the ANPP and was later used to support both government nuclear operations and commercial fuel assembly evaluations. The hot shop is a 50- $\times 165$-ft concrete-shielded high bay with a 55-ft ceiling. Large overhead manipulators, three wall-mounted manipulators, and remote handling equipment are located in the bay for radioactive materials operations. The hot shop walls and ceiling are constructed of reinforced concrete. Shielded operating galleries are located at two elevations outside the north and south walls of the hot shop and include viewing windows for remote operations. Access to the storage pool and the hot cell is available from the hot shop. The west wall, adjacent to the hot shop extension, has a 28 -ft-high $\times 33$-ft-wide door that was used as a truck and locomotive entrance. The hot shop extension provided a waiting area for trucks and components entering the hot shop and was also used for temporary storage of waste and other 


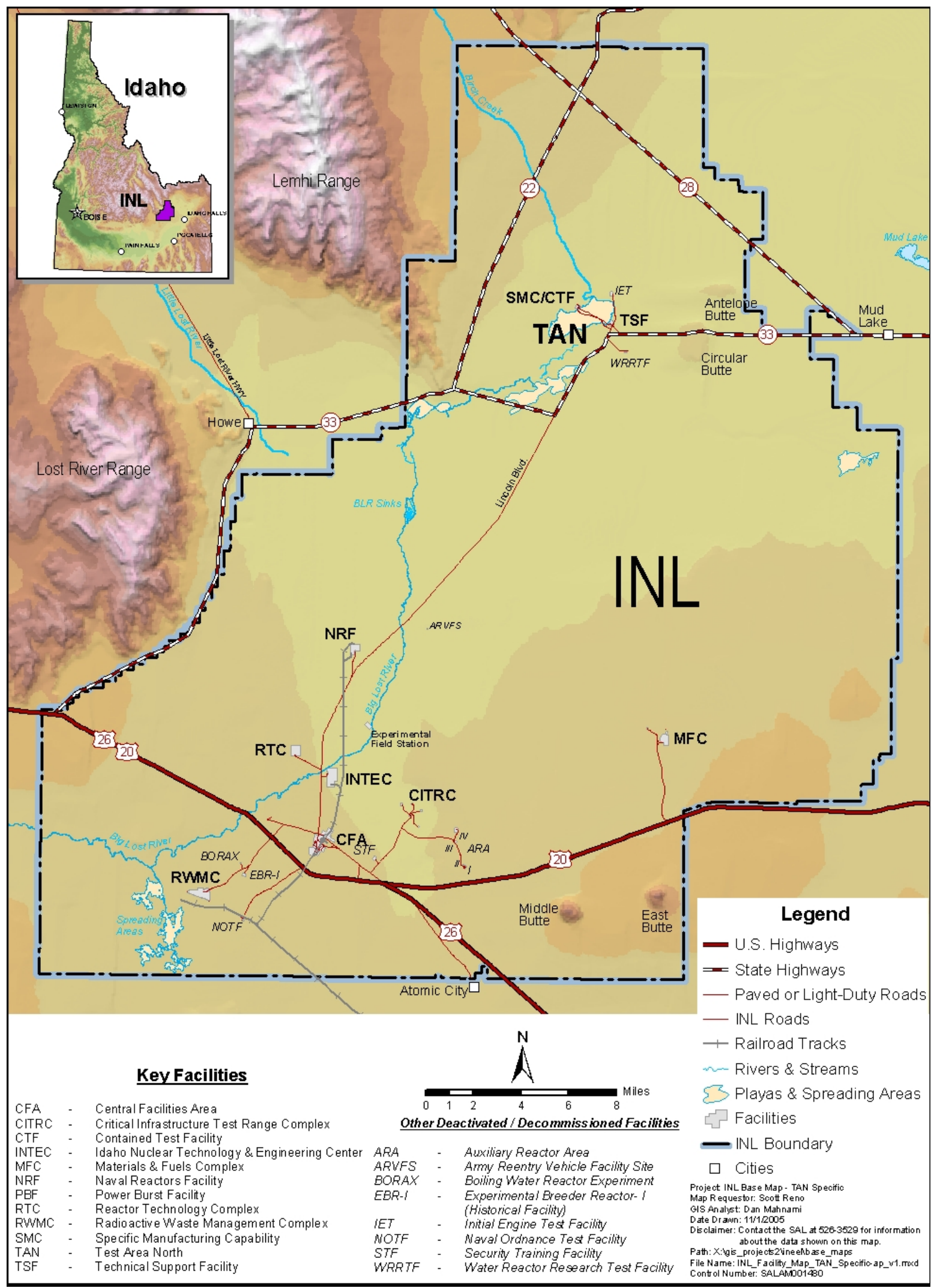

Figure 1. Idaho National Laboratory Site. 


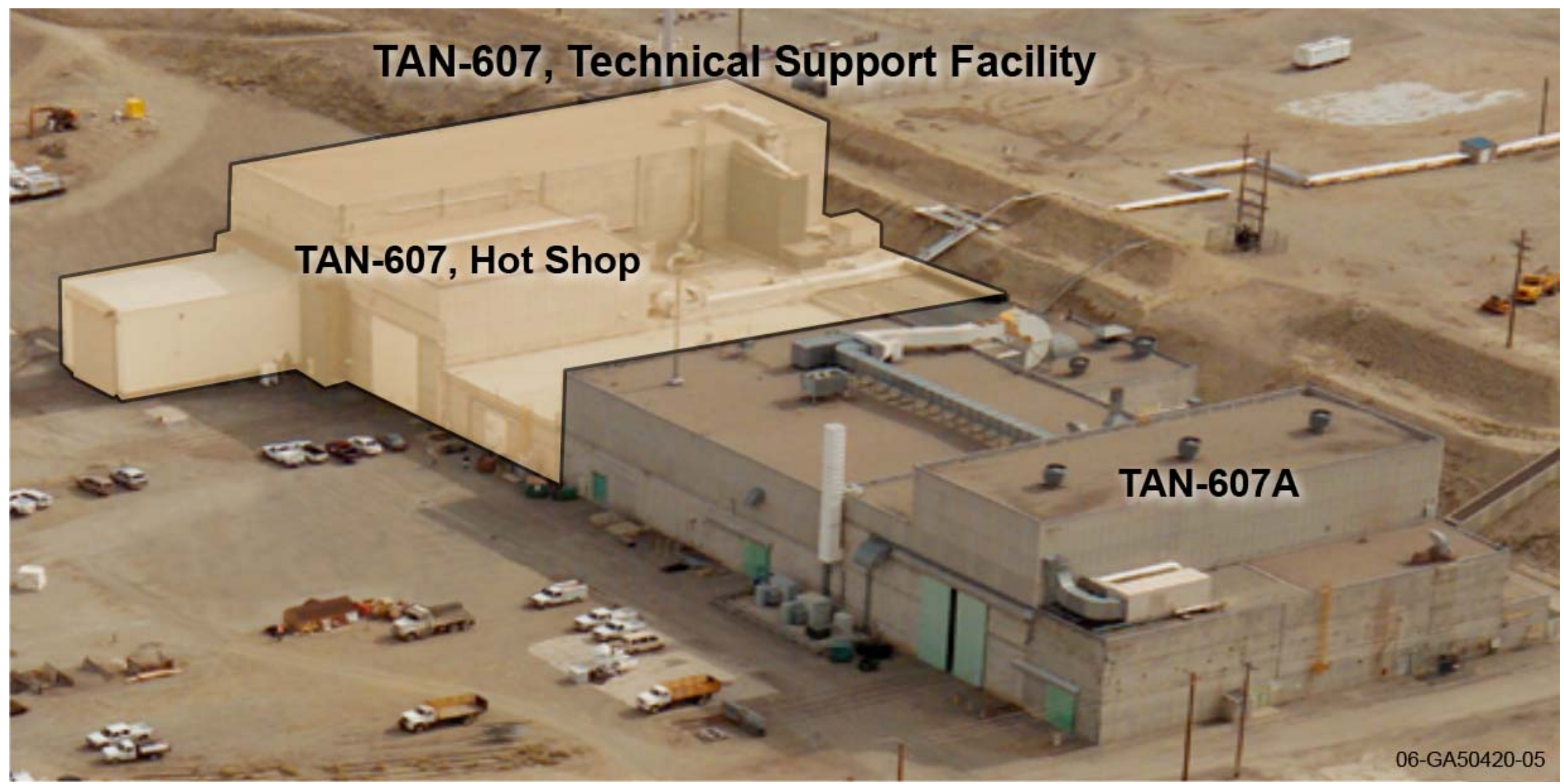

Figure 2. TAN-607, Technical Support Facility (looking northeast). 


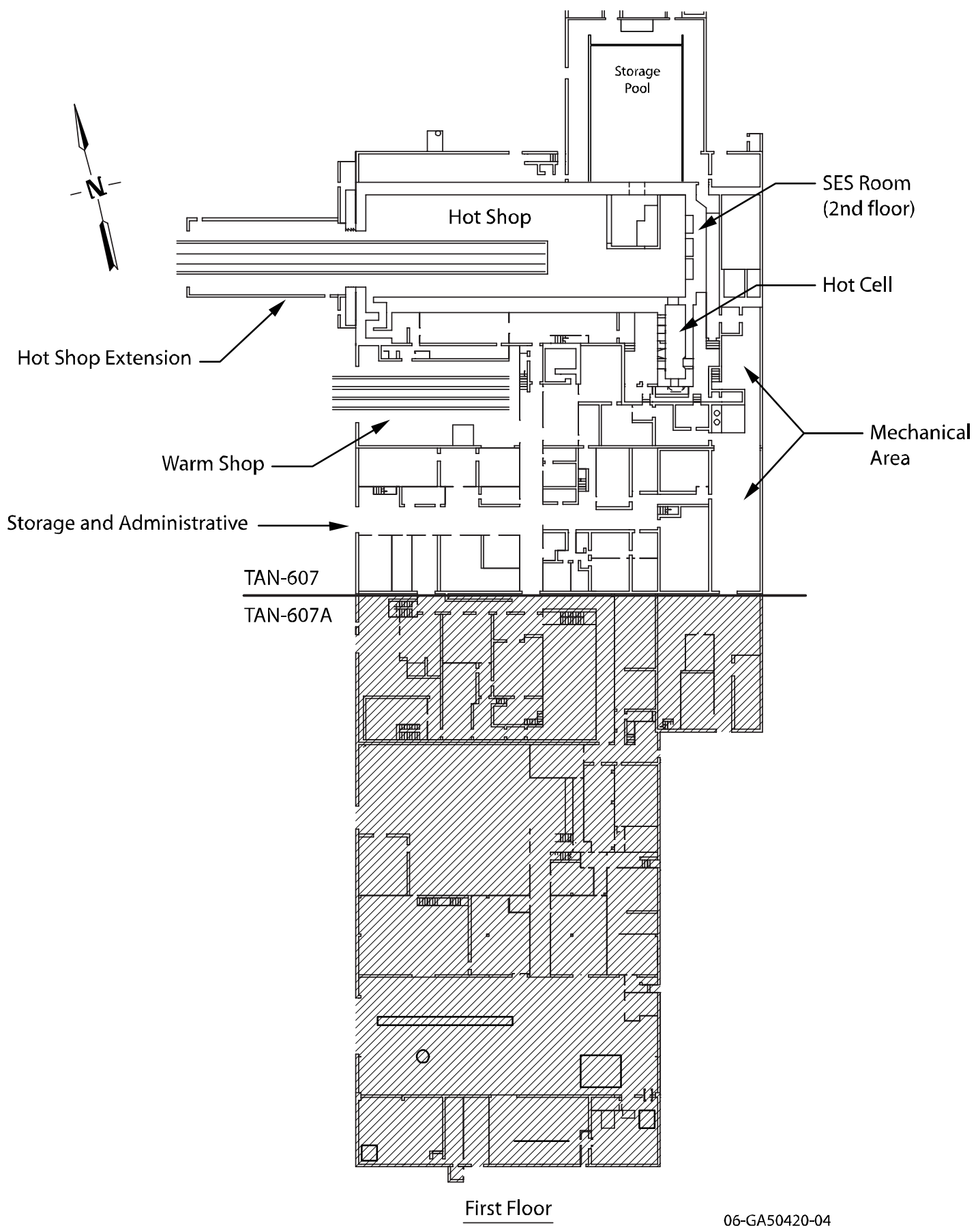

Figure 3. TAN-607, Technical Support Facility, interior view.

materials. The SES room is an extension of the hot shop on the east side. The SES room floor level is $13 \mathrm{ft}$ above the hot shop floor level and was used for shielded maintenance of the overhead crane and manipulators.

The 24-ft-deep storage pool was used for underwater storage of fissile and radioactive materials. A passageway under the north hot shop wall connects the storage pool to the storage pool vestibule that is located in the hot shop. All spent nuclear fuel items that were stored in the storage pool have been 
removed. The water has been removed and the walls and floors of the storage pool and vestibule have been cleaned and sealed to control the spread of radiological contamination.

The hot cell, formerly known as the Radioactive Materials Laboratory, is located adjacent to the southeast corner of the hot shop. The hot cell is a typical hot cell that was used for conventional remote physical and chemical inspections and tests. The hot cell was also used for small-scale assembly and disassembly operations (e.g., disassembly and assembly of fuel rods). The hot cell is a $10-\times 35-\times 20$-ft-high cell constructed with 4-ft-thick high-density concrete walls. The walls and floors are lined with a 1/4-in.-thick stainless-steel liner. Hot cell viewing windows are filled with mineral oil.

The warm shop was originally used as an assembly area for nonradioactive components and complete nuclear systems and functioned as a cold assembly area. When the TAN-607A High Bay Area became operational, the warm shop was then used for assembly and maintenance of low-activity radioactive components as well as for receiving and staging of contained hot assemblies and components waiting for processing in the hot shop, hot cell, or hot cell annex. The welding shop and carpentry shop are both currently located in the warm shop.

Other support areas included administrative office, storage, and mechanical areas. An example of the latter is the equipment room that housed the demineralized water system tanks, air cleaning tanks, and tanks associated with the boiler system.

\subsection{Previous Closure/Cleanup Activities at TAN}

Recent CERCLA activities at TAN have been focused predominantly at the TSF area. In addition, since 2004, 62 buildings and structures have been decommissioned at the TSF and at the LOFT facility (Engineering Evaluation/Cost Analysis (EE/CA) for Decommissioning of TAN-630 and TAN-650 Loss-of-Fluid Test (LOFT) Area [DOE-ID 2006a]) along with the completion of several HWMA/RCRA activities.

\subsubsection{CERCLA Activities}

CERCLA remedial actions have occurred or will occur in accordance with the Final Record of Decision, Test Area North, Operable Unit 1-10 (DOE-ID 1999). These CERCLA remedial actions are addressed as follows:

- V-Tanks (TSF-09 and TSF-18): This action is expected to be completed in the summer of 2007.

- $\quad$ PM-2A Tanks (TSF-26): This action was completed during the summer of 2005.

- $\quad$ Soil Contamination Area South of the Turntable (TSF-06, Area B): This action was completed during the summer of 2004.

- $\quad$ Disposal Pond (TSF-07): This action is on hold until decommissioning of the TAN Hot Shop Area is complete.

- $\quad$ Burn Pits (TSF-03 and WRRTF-01): This action was completed during the fall of 2004.

- $\quad$ Fuel Leak (WRRTF-13): This action was completed during the summer of 2004.

As noted above, several CERCLA remediation efforts have been completed (e.g., the PM-2A Tanks, burn pits) while others are still ongoing. For two sites, the TSF Injection Well (TSF-05) and the Contaminated Ground Water Beneath TSF (TSF-23), the CERCLA remedial action is being implemented under the Operable Unit (OU) 1-07B ROD (DOE-ID 1995). 
Two NTCRAs are being conducted at TAN at this time. TAN-607A is addressed in Engineering Evaluation/Cost Analysis (EE/CA) Decommissioning of TAN-607A (ICP 2006), and other buildings and structures not part of TAN-607 are included in Engineering Evaluation/Cost Analysis (EE/CA) for General Decommissioning Activities under the Idaho Cleanup Project (DOE-ID 2006b). If any newly identified release site(s) are discovered, DOE-ID will consult with the Idaho Department of Environmental Quality (DEQ) and EPA regarding remediation under this EE/CA; or, if the extent of contamination is beyond the footprint to be addressed under this EE/CA, the site(s) will be addressed under the FFA/CO (DOE-ID 1991) or other regulatory programs.

\subsubsection{Voluntary Consent Order HWMA/RCRA Closure Activities}

Voluntary Consent Order (VCO) actions are being implemented to ensure compliance with HWMA/RCRA regulations. The VCO is a consent order between DOE-ID and DEQ to address potential HWMA/RCRA waste issues. All VCO actions at TAN-607 have been completed except the characterization and removal of any solid materials determined to be hazardous waste in the lines and trenches in the Hot Shop Area. The VCO actions are outside of the scope of this EE/CA.

\subsection{Cleanup Activities Currently Ongoing at TAN-607 Hot Shop Area}

Currently, deactivation actions are being performed. The actions include asbestos abatement, utility isolation, decontamination, removing the radiologically contaminated ventilation system, and sampling and removing the radiologically contaminated filter banks. All potential HWMA/RCRA and TSCA materials are also being removed. This includes, but is not limited to, lead, circuit boards, mercury switches, ballasts, and fluorescent tubes. These materials are being characterized and dispositioned per appropriate regulatory requirements as they are removed.

\subsection{Extent of Contamination and Remaining Inventories}

\subsubsection{Remaining Radionuclide Inventory}

To determine the radiological content for TAN-607, a number of methods were employed, including extensive scans and wipes of building surfaces, dose rate surveys, in situ gamma spectroscopy, and/or sampling and laboratory analysis for the various isotopes and radiations potentially present (gamma, alpha, pure beta-emitters). Where available, existing characterization information from historical documents and Engineering Design Files (EDFs) was used. Numerous samples have been taken over the life of the facility and waste streams for TAN-607 consistently contain primarily reactor-produced isotopes Cs-137, Sr-90, and Co-60. This holds true for the hot shop, hot cell, empty storage pool and vestibule, and hot cell drains for which these three isotopes account for the vast majority, over $90 \%$, of activity present. Alpha-emitters typically account for less than $1 \%$ of total activity in the TAN-607 Hot Shop Area.

The radiological inventory estimate for the TAN-607 building structure is $77 \mathrm{Ci}$ (October 2006) based on radiological surveys, in situ measurements, conservative assumptions, and scaling of hard-to-detect nuclides (Table 1). The source term is confined to the hot shop, hot cell, and the empty storage pool since the minor amounts of fixed radiological contamination outside of these areas will be decontaminated or already meet the RAOs. 
Table 1. Summary of radiological activity in TAN-607 (in curies) in 2006 and decayed to 2095.

\begin{tabular}{|c|c|c|c|c|c|c|}
\hline Radionuclide & $\begin{array}{c}\text { Hot Shop } \\
\text { and Tunnel }\end{array}$ & Storage Pool & TAN Hot Cell & $\begin{array}{c}\text { Hot Shop } \\
\text { Sumps/Drains }\end{array}$ & $\begin{array}{c}\text { Total } \\
\text { 2006 Curies } \\
\end{array}$ & $\begin{array}{c}\text { Total } \\
2095 \text { Curies } \\
\end{array}$ \\
\hline $\mathrm{Ag}-108 \mathrm{~m}$ & $-^{\mathrm{a}}$ & - & - & $5.58 \mathrm{E}-04$ & $5.58 \mathrm{E}-04$ & $3.43 \mathrm{E}-04$ \\
\hline Am-241 & $5.99 \mathrm{E}-02$ & 7.92E-02 & $9.50 \mathrm{E}-03$ & 4.48E-01 & $5.97 \mathrm{E}-01$ & $6.83 \mathrm{E}-01$ \\
\hline $\mathrm{C}-14$ & - & - & - & $2.74 \mathrm{E}-04$ & $2.74 \mathrm{E}-04$ & $2.71 \mathrm{E}-04$ \\
\hline $\mathrm{Cm}-242$ & - & - & $4.28 \mathrm{E}-07$ & - & $4.28 \mathrm{E}-07$ & $4.68 \mathrm{E}-67$ \\
\hline $\mathrm{Cm}-244$ & - & - & $1.35 \mathrm{E}-03$ & - & $1.35 \mathrm{E}-03$ & $4.48 \mathrm{E}-05$ \\
\hline Co-60 & $5.30 \mathrm{E}-01$ & 7.01E-01 & $7.76 \mathrm{E}-04$ & $1.05 \mathrm{E}-01$ & $1.34 \mathrm{E}+00$ & $1.11 \mathrm{E}-05$ \\
\hline Cs-137 & $6.17 \mathrm{E}+00$ & $8.18 \mathrm{E}+00$ & $1.15 \mathrm{E}-01$ & $1.56 \mathrm{E}+01$ & $3.01 \mathrm{E}+01$ & $3.90 \mathrm{E}+00$ \\
\hline Eu-152 & - & - & $1.43 \mathrm{E}-03$ & - & $1.43 \mathrm{E}-03$ & $1.53 \mathrm{E}-05$ \\
\hline Eu-154 & - & - & $2.47 \mathrm{E}-03$ & - & $2.47 \mathrm{E}-03$ & $2.23 \mathrm{E}-05$ \\
\hline Eu-155 & - & - & 4.60E-04 & - & 4.60E-04 & $1.82 \mathrm{E}-09$ \\
\hline $\mathrm{H}-3$ & $2.81 \mathrm{E}-02$ & $3.72 \mathrm{E}-02$ & - & $6.24 \mathrm{E}-02$ & $1.28 \mathrm{E}-01$ & $8.42 \mathrm{E}-04$ \\
\hline $\mathrm{I}-129^{\mathrm{b}}$ & - & $1.38 \mathrm{E}-04$ & - & - & $1.38 \mathrm{E}-04$ & $1.38 \mathrm{E}-04$ \\
\hline $\mathrm{Ni}-63$ & $1.39 \mathrm{E}-01$ & $1.84 \mathrm{E}-01$ & - & 4.19E-01 & 7.42E-01 & $4.01 \mathrm{E}-01$ \\
\hline Np-237 & - & - & $2.18 \mathrm{E}-06$ & - & $2.18 \mathrm{E}-06$ & $2.22 \mathrm{E}-05$ \\
\hline $\mathrm{Pu}-238$ & $1.14 \mathrm{E}-02$ & $1.51 \mathrm{E}-02$ & $6.92 \mathrm{E}-03$ & 4.37E-02 & 7.71E-02 & $3.82 \mathrm{E}-02$ \\
\hline Pu-239 & 4.49E-02 & $5.94 \mathrm{E}-02$ & 4.87E-03 & 4.22E-01 & $5.31 \mathrm{E}-01$ & $5.30 \mathrm{E}-01$ \\
\hline $\mathrm{Pu}-240$ & $4.49 \mathrm{E}-02$ & 5.94E-02 & - & - & $1.04 \mathrm{E}-01$ & $1.03 \mathrm{E}-01$ \\
\hline $\mathrm{Pu}-241$ & $7.78 \mathrm{E}-01$ & $1.03 \mathrm{E}+00$ & $1.23 \mathrm{E}-01$ & $3.71 \mathrm{E}+00$ & $5.64 \mathrm{E}+00$ & $7.78 \mathrm{E}-02$ \\
\hline Sr-90 & $5.48 \mathrm{E}+00$ & $7.26 \mathrm{E}+00$ & $1.77 \mathrm{E}-01$ & $2.48 \mathrm{E}+01$ & $3.77 \mathrm{E}+01$ & $4.36 \mathrm{E}+00$ \\
\hline Tc-99 & - & - & $3.60 \mathrm{E}-05$ & - & $3.60 \mathrm{E}-05$ & $3.60 \mathrm{E}-05$ \\
\hline U-233 & $1.99 \mathrm{E}-03$ & $2.63 \mathrm{E}-03$ & - & $2.05 \mathrm{E}-03$ & $6.67 \mathrm{E}-03$ & $6.67 \mathrm{E}-03$ \\
\hline U-234 & $1.99 \mathrm{E}-03$ & $2.63 \mathrm{E}-03$ & $1.25 \mathrm{E}-04$ & $2.05 \mathrm{E}-03$ & $6.80 \mathrm{E}-03$ & $6.81 \mathrm{E}-03$ \\
\hline U-235 & $1.32 \mathrm{E}-04$ & $1.75 \mathrm{E}-04$ & $6.70 \mathrm{E}-06$ & $5.23 \mathrm{E}-04$ & 8.37E-04 & 8.37E-04 \\
\hline U-238 & $3.30 \mathrm{E}-04$ & $4.38 \mathrm{E}-04$ & 7.11E-06 & $9.24 \mathrm{E}-04$ & $1.70 \mathrm{E}-03$ & $1.70 \mathrm{E}-03$ \\
\hline Total & $1.33 \mathrm{E}+01$ & $1.76 \mathrm{E}+01$ & 4.43E-01 & $4.56 \mathrm{E}+01$ & $7.70 \mathrm{E}+01$ & $1.03 \mathrm{E}+01$ \\
\hline \multicolumn{7}{|c|}{$\begin{array}{l}\text { Notes: } \\
\text { Cs-137 and Sr-90 daughters Ba-137m and Y-90 not reported. } \\
2006 \text { isotopes decayed to } 2095 \text { in Microshield v. } 6.20 \text { licensed to INL. (Areva 2004) }\end{array}$} \\
\hline
\end{tabular}

\subsubsection{Remaining Nonradionuclide Inventory}

Extensive nonradiological characterization has been completed in TAN-607. As discussed above, potential HWMA/RCRA issues have been or are being addressed under the terms of the VCO. All other nonradiological contamination is expected to be removed as part of the deactivation activities; therefore, no nonradiological inventory is addressed under this EE/CA.

\subsection{Risk Assessment}

An assessment was completed to project the potential risk from TAN-607 if no action were taken as described under Alternative 1. As stated above, the No Action alternative is a hypothetical and conservative "baseline" assumption, in that the sum of identified radiological contamination, if not properly contained or controlled, may be released to the environment causing a potential risk to receptors 
(current and future workers, hypothetical future residents, and the environment). These assumptions used in the risk assessments are "worst case" and are for comparative purposes. Although conservative, the results of the risk assessment do indicate that, if no action were taken, an increased risk to human health and the environment would exist.

\subsubsection{Risk Assessment from Radiological Source Term}

The risk assessments conducted include the groundwater assessments as described in EDF-7515, "Groundwater Assessment for TAN-607: Hot Shop Area," and a risk assessment conducted as per RiskBased Screening and Assessment Approach for Waste Area Group 1 Soils (VanHorn and Stacey 2004). These risk analyses did not evaluate nonradiological constituents because, under all alternatives, the nonradiological constituents are removed.

The current inventory of $77 \mathrm{Ci}$ is evaluated to project a hypothetical risk if no action is taken to reduce the radiological source term. The majority of the radionuclide inventories from Table 1 were used directly as input to the risk assessments. However, for a few nuclides the risk is from the ingrowth and subsequent progeny rather than transport of the parent radionuclides. Therefore, it is conservatively assumed that all of the original inventory of Am-241 and Pu-241 instantaneously decays to Np-237 and is added to the original $\mathrm{Np}-237$ inventory as input for the risk assessment. It is also assumed that $\mathrm{Cm}-242$ and $\mathrm{Pu}-238$ instantaneously decays to U-234 and Cm-244 instantaneously decays to Pu-240 and are added to theses original inventories respectively.

The assessment code GWSCREEN 2.5a (version update 08/11/2005) (Rood 2003) was the numerical tool used to conduct the groundwater risk assessment. The groundwater assessment is based on the approach and assumptions in the document Track 2 Sites: Guidance for Assessing Low Probability Hazard Sites at the INEL (DOE-ID 1994). The Track 2 approach was developed specifically for the INL to streamline the implementation of CERCLA. The Track 2 groundwater model assumptions and parameter values assigned were chosen to provide a conservative estimate of the groundwater pathway risk.

The source term for the Track 2 assessment is assumed to be soils; therefore, a "worst case" risk assessment was completed for the soils. However, for TAN-607, the contamination is currently on or embedded in the top surface of the concrete slab. In order for the contamination to reach the vadose zone and be transported to the aquifer, the concrete slab must degrade to the point that water can leach through it. At that time, the contaminants can be transported, by water, into and then through the concrete slab. Water chemistry within the concrete is assumed to be different than the water chemistry in native soils. This chemistry difference is assumed to affect the transport of the radionuclides. Contaminants are generally less mobile in a concrete chemical environment than in the INL native soils. Therefore, in addition to the "bounding" groundwater risk assessment with the Track 2 assumptions for soils, a second set of calculations was conducted using concrete-water partition coefficients for contaminants in the concrete slab.

The predicted peak and maximum average aquifer concentrations, time of peak, and maximum risk results for the groundwater risk assessment for both soils and concrete are summarized in Table 2 . Concrete $\mathrm{K}_{\mathrm{d}} \mathrm{S}$ are not readily available for all of the radionuclides. Therefore, radionuclides with predicted very low risks, assuming a soil source for which concrete $\mathrm{K}_{\mathrm{d}}$ values are not available (Ag-108m, Co-60, Cs-137, Eu-152, Eu-154, Eu-155, H-3, and Ni-63), are not resimulated and are identified in Table 2 with "NA." 
Table 2. Groundwater pathway risk assessment results.

\begin{tabular}{|c|c|c|c|c|c|c|c|c|c|c|}
\hline \multirow[b]{2}{*}{ Parent } & \multirow[b]{2}{*}{ Progeny } & \multirow[b]{2}{*}{$\begin{array}{l}\text { Estimated } \\
\text { Inventory } \\
\text { (Ci) }\end{array}$} & \multicolumn{4}{|c|}{ Soil Source Term } & \multicolumn{4}{|c|}{ Concrete Source Term } \\
\hline & & & $\begin{array}{l}\text { Predicted Peak } \\
\text { Concentration } \\
(\mathrm{pCi} / \mathrm{L})\end{array}$ & $\begin{array}{c}\text { Years to Peak } \\
\text { Concentration } \\
\text { (years) }\end{array}$ & $\begin{array}{l}\text { Peak 30-yr } \\
\text { Average } \\
\text { Concentration } \\
\text { (pCi/L) }\end{array}$ & $\begin{array}{c}\text { Maximum } \\
\text { Risk }\end{array}$ & $\begin{array}{l}\text { Predicted Peak } \\
\text { Concentration } \\
(\mathrm{pCi} / \mathrm{L})\end{array}$ & $\begin{array}{c}\text { Years to Peak } \\
\text { Concentration } \\
\text { (years) }\end{array}$ & $\begin{array}{l}\text { Peak 30-yr } \\
\text { Average } \\
\text { Concentration } \\
\text { (pCi/L) }\end{array}$ & $\begin{array}{c}\text { Maximum } \\
\text { Risk }\end{array}$ \\
\hline Ag-108m & & $5.58 \mathrm{E}-04$ & $3.09 \mathrm{E}-06$ & $5.43 \mathrm{E}+03$ & $2.75 \mathrm{E}-06$ & $5 \mathrm{E}-13$ & $\mathrm{NA}^{\mathrm{a}}$ & NA & NA & NA \\
\hline $\mathrm{C}-14$ & & $2.74 \mathrm{E}-04$ & $3.43 \mathrm{E}+00$ & $1.82 \mathrm{E}+01$ & $2.33 \mathrm{E}-01$ & $8 \mathrm{E}-09$ & $1.14 \mathrm{E}-03$ & $2.13 \mathrm{E}+01$ & $1.14 \mathrm{E}-03$ & $4 \mathrm{E}-11$ \\
\hline Co-60 & & $1.34 \mathrm{E}+00$ & $4.80 \mathrm{E}-33$ & $6.13 \mathrm{E}+02$ & $1.27 \mathrm{E}-33$ & $<1 \mathrm{E}-20$ & NA & NA & NA & NA \\
\hline Cs-137 & & $3.01 \mathrm{E}+01$ & $0.00 \mathrm{E}+00$ & $5.08 \mathrm{E}+04$ & $0.00 \mathrm{E}+00$ & $<1 \mathrm{E}-20$ & NA & NA & NA & NA \\
\hline Eu-152 & & $1.43 \mathrm{E}-03$ & $0.00 \mathrm{E}+00$ & $2.44 \mathrm{E}+04$ & $0.00 \mathrm{E}+00$ & $<1 \mathrm{E}-20$ & NA & NA & NA & NA \\
\hline Eu-154 & & $2.47 \mathrm{E}-03$ & $0.00 \mathrm{E}+00$ & $2.44 \mathrm{E}+04$ & $0.00 \mathrm{E}+00$ & $<1 \mathrm{E}-20$ & NA & NA & NA & NA \\
\hline Eu-155 & & $4.60 \mathrm{E}-04$ & $0.00 \mathrm{E}+00$ & $2.44 \mathrm{E}+04$ & $0.00 \mathrm{E}+00$ & $<1 \mathrm{E}-20$ & NA & NA & NA & NA \\
\hline $\mathrm{H}-3$ & & $1.28 \mathrm{E}-01$ & $1.18 \mathrm{E}+03$ & $1.22 \mathrm{E}+01$ & $5.25 \mathrm{E}+01$ & $1 \mathrm{E}-07$ & NA & NA & NA & NA \\
\hline $\mathrm{I}-129$ & & $1.38 \mathrm{E}-04$ & $2.52 \mathrm{E}+00$ & $1.22 \mathrm{E}+01$ & $1.19 \mathrm{E}-01$ & $4 \mathrm{E}-07$ & $2.57 \mathrm{E}-01$ & $1.23 \mathrm{E}+01$ & $1.04 \mathrm{E}-01$ & $3 \mathrm{E}-07$ \\
\hline $\mathrm{Ni}-63$ & & 7.42E-01 & $2.15 \mathrm{E}-17$ & $6.03 \mathrm{E}+03$ & $1.88 \mathrm{E}-17$ & $<1 \mathrm{E}-20$ & NA & NA & NA & NA \\
\hline $\mathrm{Np}-237^{\mathrm{b}}$ & $\begin{array}{l}\text { U-233 } \\
\text { Th-229 }\end{array}$ & $1.60 \mathrm{E}-04$ & $\begin{array}{l}7.87 \mathrm{E}-02 \\
2.16 \mathrm{E}-04 \\
3.57 \mathrm{E}-07\end{array}$ & $4.94 \mathrm{E}+02$ & $\begin{array}{l}6.05 \mathrm{E}-02 \\
1.70 \mathrm{E}-04 \\
2.88 \mathrm{E}-07\end{array}$ & $8 \mathrm{E}-08$ & $\begin{array}{l}1.34 \mathrm{E}-04 \\
3.82 \mathrm{E}-07 \\
6.59 \mathrm{E}-10 \\
\end{array}$ & $5.14 \mathrm{E}+02$ & $\begin{array}{l}1.34 \mathrm{E}-04 \\
3.82 \mathrm{E}-07 \\
6.59 \mathrm{E}-10 \\
\end{array}$ & $2 \mathrm{E}-10$ \\
\hline $\mathrm{Pu}-239$ & $\begin{array}{l}\text { U-235 } \\
\text { Pa-231 } \\
\text { Ac-227 }\end{array}$ & $5.31 \mathrm{E}-01$ & $\begin{array}{c}9.31 \mathrm{E}+01 \\
3.98 \mathrm{E}-04 \\
7.43 \mathrm{E}-08 \\
8.67 \mathrm{E}-08\end{array}$ & $1.34 \mathrm{E}+03$ & $\begin{array}{c}8.38 \mathrm{E}+01 \\
3.61 \mathrm{E}-04 \\
6.80 \mathrm{E}-08 \\
7.93 \mathrm{E}-08\end{array}$ & $2 \mathrm{E}-04$ & $\begin{array}{l}4.27 \mathrm{E}-01 \\
1.83 \mathrm{E}-06 \\
3.44 \mathrm{E}-10 \\
4.01 \mathrm{E}-10\end{array}$ & $1.34 \mathrm{E}+03$ & $\begin{array}{l}4.14 \mathrm{E}-01 \\
1.79 \mathrm{E}-06 \\
3.36 \mathrm{E}-10 \\
3.92 \mathrm{E}-10\end{array}$ & $1 \mathrm{E}-06$ \\
\hline $\mathrm{Pu}-240^{\mathrm{b}}$ & $\begin{array}{l}\text { U-236 } \\
\text { Th-232 } \\
\text { Ra-228 } \\
\text { Th-228 }\end{array}$ & $1.04 \mathrm{E}-01$ & $\begin{array}{l}1.65 \mathrm{E}+01 \\
2.23 \mathrm{E}-03 \\
5.41 \mathrm{E}-12 \\
9.19 \mathrm{E}-13 \\
9.13 \mathrm{E}-13\end{array}$ & $1.34 \mathrm{E}+03$ & $\begin{array}{l}1.48 \mathrm{E}+01 \\
2.02 \mathrm{E}-03 \\
4.95 \mathrm{E}-12 \\
8.46 \mathrm{E}-13 \\
8.41 \mathrm{E}-13\end{array}$ & $4 \mathrm{E}-05$ & $\begin{array}{l}7.55 \mathrm{E}-02 \\
1.03 \mathrm{E}-05 \\
2.50 \mathrm{E}-14 \\
4.25 \mathrm{E}-15 \\
4.23 \mathrm{E}-15\end{array}$ & $1.34 \mathrm{E}+03$ & $\begin{array}{l}7.31 \mathrm{E}-02 \\
9.99 \mathrm{E}-06 \\
2.45 \mathrm{E}-14 \\
4.19 \mathrm{E}-15 \\
4.16 \mathrm{E}-15\end{array}$ & 2E-07 \\
\hline
\end{tabular}


Table 2. (continued).

\begin{tabular}{|c|c|c|c|c|c|c|c|c|c|c|}
\hline \multirow[b]{2}{*}{ Parent } & \multirow[b]{2}{*}{ Progeny } & \multirow[b]{2}{*}{$\begin{array}{l}\text { Estimated } \\
\text { Inventory } \\
\text { (Ci) }\end{array}$} & \multicolumn{4}{|c|}{ Soil Source Term } & \multicolumn{4}{|c|}{ Concrete Source Term } \\
\hline & & & $\begin{array}{l}\text { Predicted Peak } \\
\text { Concentration } \\
(\mathrm{pCi} / \mathrm{L})\end{array}$ & $\begin{array}{c}\text { Years to Peak } \\
\text { Concentration } \\
\text { (years) }\end{array}$ & $\begin{array}{l}\text { Peak 30-yr } \\
\text { Average } \\
\text { Concentration } \\
\text { (pCi/L) }\end{array}$ & $\begin{array}{c}\text { Maximum } \\
\text { Risk }\end{array}$ & $\begin{array}{l}\text { Predicted Peak } \\
\text { Concentration } \\
(\mathrm{pCi} / \mathrm{L})\end{array}$ & $\begin{array}{c}\text { Years to Peak } \\
\text { Concentration } \\
\text { (years) }\end{array}$ & $\begin{array}{l}\text { Peak 30-yr } \\
\text { Average } \\
\text { Concentration } \\
\text { (pCi/L) }\end{array}$ & $\begin{array}{l}\text { Maximum } \\
\text { Risk }\end{array}$ \\
\hline Sr-90 & & $3.77 \mathrm{E}+01$ & $2.64 \mathrm{E}-04$ & $7.34 \mathrm{E}+02$ & $1.69 \mathrm{E}-04$ & $3 \mathrm{E}-10$ & $2.34 \mathrm{E}-03$ & $7.33 \mathrm{E}+02$ & $5.87 \mathrm{E}-04$ & $9 \mathrm{E}-10$ \\
\hline Tc-99 & & $3.60 \mathrm{E}-05$ & $3.44 \mathrm{E}-01$ & $2.42 \mathrm{E}+01$ & $3.06 \mathrm{E}-02$ & 2E-09 & $1.51 \mathrm{E}-04$ & $2.77 \mathrm{E}+01$ & $1.50 \mathrm{E}-04$ & $9 \mathrm{E}-12$ \\
\hline U-233 & Th-229 & $6.67 \mathrm{E}-03$ & $\begin{array}{r}4.33 \mathrm{E}+00 \\
1.08 \mathrm{E}-02 \\
\end{array}$ & $3.73 \mathrm{E}+02$ & $\begin{array}{l}3.06 \mathrm{E}+00 \\
7.91 \mathrm{E}-03\end{array}$ & $5 \mathrm{E}-06$ & $\begin{array}{l}5.57 \mathrm{E}-03 \\
1.46 \mathrm{E}-05 \\
\end{array}$ & $3.90 \mathrm{E}+02$ & $\begin{array}{l}5.57 \mathrm{E}-03 \\
1.45 \mathrm{E}-05 \\
\end{array}$ & 9E-09 \\
\hline $\mathrm{U}-234^{\mathrm{b}}$ & $\begin{array}{l}\text { Th-230 } \\
\text { Ra-226 } \\
\mathrm{Pb}-210 \\
\end{array}$ & $6.83 \mathrm{E}-03$ & $\begin{array}{l}4.44 \mathrm{E}+00 \\
1.10 \mathrm{E}-03 \\
8.42 \mathrm{E}-05 \\
7.13 \mathrm{E}-05\end{array}$ & $3.73 \mathrm{E}+02$ & $\begin{array}{l}3.14 \mathrm{E}+00 \\
8.02 \mathrm{E}-04 \\
6.34 \mathrm{E}-05 \\
5.39 \mathrm{E}-05\end{array}$ & $5 \mathrm{E}-06$ & $\begin{array}{l}5.71 \mathrm{E}-03 \\
1.48 \mathrm{E}-06 \\
1.18 \mathrm{E}-07 \\
1.00 \mathrm{E}-07\end{array}$ & $3.90 \mathrm{E}+02$ & $\begin{array}{l}5.71 \mathrm{E}-03 \\
1.47 \mathrm{E}-06 \\
1.18 \mathrm{E}-07 \\
1.00 \mathrm{E}-07\end{array}$ & $8 \mathrm{E}-09$ \\
\hline U-235 & $\begin{array}{l}\text { Pa-231 } \\
\text { Ac-227 }\end{array}$ & $8.37 \mathrm{E}-04$ & $\begin{array}{l}5.44 \mathrm{E}-01 \\
5.67 \mathrm{E}-05 \\
6.35 \mathrm{E}-05\end{array}$ & $3.73 \mathrm{E}+02$ & $\begin{array}{l}3.85 \mathrm{E}-01 \\
4.14 \mathrm{E}-05 \\
4.65 \mathrm{E}-05\end{array}$ & $6 \mathrm{E}-07$ & $\begin{array}{l}7.00 \mathrm{E}-04 \\
7.62 \mathrm{E}-08 \\
8.56 \mathrm{E}-08\end{array}$ & $3.90 \mathrm{E}+02$ & $\begin{array}{l}7.00 \mathrm{E}-04 \\
7.62 \mathrm{E}-08 \\
8.56 \mathrm{E}-08\end{array}$ & $1 \mathrm{E}-09$ \\
\hline U-238 & $\begin{array}{l}\mathrm{U}-234 \\
\mathrm{Th}-230 \\
\mathrm{Ra}-226 \\
\mathrm{~Pb}-210\end{array}$ & $1.70 \mathrm{E}-03$ & $\begin{array}{l}1.11 \mathrm{E}+00 \\
1.16 \mathrm{E}-03 \\
1.44 \mathrm{E}-07 \\
7.45 \mathrm{E}-09 \\
5.85 \mathrm{E}-09\end{array}$ & $3.73 \mathrm{E}+02$ & $\begin{array}{l}7.82 \mathrm{E}-01 \\
8.49 \mathrm{E}-04 \\
1.08 \mathrm{E}-07 \\
5.80 \mathrm{E}-09 \\
4.58 \mathrm{E}-09\end{array}$ & $1 \mathrm{E}-06$ & $\begin{array}{l}1.42 \mathrm{E}-03 \\
1.56 \mathrm{E}-06 \\
2.02 \mathrm{E}-10 \\
1.09 \mathrm{E}-11 \\
8.63 \mathrm{E}-12\end{array}$ & $3.90 \mathrm{E}+02$ & $\begin{array}{l}1.42 \mathrm{E}-03 \\
1.56 \mathrm{E}-06 \\
2.02 \mathrm{E}-10 \\
1.09 \mathrm{E}-11 \\
8.64 \mathrm{E}-12\end{array}$ & 2E-09 \\
\hline Total & & $7.70 \mathrm{E}+01$ & & & & & & & & \\
\hline $\begin{array}{l}\text { a. NA iden } \\
\text { b. The Np- } \\
\text { from the es } \\
\text { inventory t }\end{array}$ & $\begin{array}{l}\text { nuclide } \mathrm{f} \\
\text { iventory ir } \\
\text { ed Pu-240 } \\
\text { n ever gro }\end{array}$ & $\begin{array}{l}\text { hich no conc } \\
\text { les the activi } \\
\text { ntory plus th } \\
\text { from } \mathrm{Cm}-24\end{array}$ & $\begin{array}{l}\text { parameters were } \\
\text { om the estimated } \\
\text { tal Pu-240 invento } \\
\text { dd Pu-238. }\end{array}$ & $\begin{array}{l}\text { tified. In all ca } \\
37 \text { inventory } p \\
\text { han can ever gr }\end{array}$ & $\begin{array}{l}\text { predicted risk } \\
\text { total Np-237 ir } \\
\text { com Cm-244. T }\end{array}$ & $\begin{array}{l}\text { elow the } \\
\text { ry that can } \\
234 \text { inven }\end{array}$ & $\begin{array}{l}\text { it; therefore, th } \\
\text { row in from An } \\
\text { cludes the activi }\end{array}$ & $\begin{array}{l}\text { and } \mathrm{Pu}-241 . \mathrm{Tl} \\
\mathrm{m} \text { the estimated }\end{array}$ & $\begin{array}{l}40 \text { inventory in } \\
4 \text { inventory plus }\end{array}$ & $\begin{array}{l}\text { rs. } \\
\text { tos the activity } \\
\text { total U-234 }\end{array}$ \\
\hline
\end{tabular}


The regulatory risk range used by EPA for an acceptable life time cancer risk to an individual exposure to carcinogens is between 10-4 and 10-6. When the "worst case" soil source is used, the maximum risk from the groundwater pathway is 2 in 10,000 for $\mathrm{Pu}-239$. The risk for all other radionuclides under the soil source is less than the upper bound of the EPA regulatory risk range. When the more realistic concrete source is assumed, the maximum risk dropped to 1 in 1,000,000 for $\mathrm{Pu}-239$, and, for all other radionuclides, the maximum predicted risk is less than 1 in 1,000,000. A sensitivity analysis was conducted for the radionuclides estimated to be in the TAN Hot Shop by changing the average groundwater linear velocities from 570 meters per year (velocities used in Track 2 Guidance from the ground water screening model) to 150 meters per year (actual velocities at TAN). The sensitivity analysis shows that by using the actual TAN groundwater velocity, there is less mixing which results in higher concentration and an increased risk. The change in the risk is not linear. However, there is a slight increase for the soil source for the groundwater risk assessment for Pu-239 from 2 in 10,000 to 8 in 10,000 and, for Pu-240 from 4 in 100,000 to 1 in 10,000.

The risk assessment for a residential scenario is presented in Table 3. Although the standard residential exposure scenario is considered conservative for the TAN-607 Hot Shop Area, it was used to provide a bounding risk assessment. It is considered a bounding estimate since it assumes the radiological contamination will be released all at once from the TAN-607 Hot Shop Area immediately at the end of the INL institutional control period in the year 2095. The scenario also assumes someone will build a house at the TAN-607 (even though portions of the building would remain) as soon as the institutional control period is over, $10 \mathrm{ft}$ of contaminated material will be excavated while building a basement, and the material will be spread across the surface of the housing site. Finally, the scenario assumes a person will live at the site for 30 years, including 6 years of childhood, while being exposed to contamination through soil ingestion, fugitive dust inhalation, external radiation exposure, and ingestion of contaminated fruits and vegetables grown around the house. The residential scenario risk assessment shows that the risk to a future hypothetical residential receptor is less than 1 in 10,000 (i.e., the upper bound of the EPA acceptable risk range) for all radionuclides except Tc-99 and Cs-137. The risk from Tc-99 is 5 in 10,000 and from Cs- 137 is 2 in 1,000 .

Table 3. Radiological estimated risk results for residential scenario.

\begin{tabular}{lc}
\hline Radionuclide & $\begin{array}{c}\text { Residential Scenario } \\
\text { Estimated Risk } \\
\text { (unitless) }\end{array}$ \\
\hline Ag-108m & $2 \mathrm{E}-06$ \\
C-14 & $2 \mathrm{E}-10$ \\
Co-60 & $2 \mathrm{E}-12$ \\
Cs-137 & $2 \mathrm{E}-03$ \\
Eu-152 & $1 \mathrm{E}-09$ \\
Eu-155 & $1 \mathrm{E}-11$ \\
H-3 & $3 \mathrm{E}-19$ \\
$\mathrm{I}-129$ & $1 \mathrm{E}-10$ \\
Ni-63 & $9 \mathrm{E}-09$ \\
Np-237 & $4 \mathrm{E}-07$ \\
Pu-239 & $2 \mathrm{E}-07$ \\
Pu-240 & $4 \mathrm{E}-05$ \\
Sr-90 & $6 \mathrm{E}-06$ \\
Tc-99 & $5 \mathrm{E}-04$
\end{tabular}




\begin{tabular}{lc}
\hline Radionuclide & $\begin{array}{c}\text { Residential Scenario } \\
\text { Estimated Risk } \\
\text { (unitless) }\end{array}$ \\
\hline $\mathrm{U}-233$ & $6 \mathrm{E}-11$ \\
$\mathrm{U}-234$ & $3 \mathrm{E}-07$ \\
$\mathrm{U}-235$ & $2 \mathrm{E}-07$ \\
$\mathrm{U}-238$ & $7 \mathrm{E}-07$ \\
\hline
\end{tabular}

Table 4 presents the comparison of ecologically based screening levels (EBSLs) to the maximum concentration calculated to be present in the soil in the future. EBSL screening levels are established to evaluate whether there could be an internal exposure increase to biota (plants and animals) that would result in the lack of maintenance or recovery of healthy local populations of ecological receptors that are, or should be, at or near the site. As indicated in Table 4, the only nuclide that exceeded the maximum concentration screening value was $\mathrm{Pu}-239$. No other radionuclides exceeded the screening levels.

Table 4. Comparison of calculated soil concentrations to EBSL. ${ }^{a}$

\begin{tabular}{lccc}
\hline Radionuclide & $\begin{array}{c}\text { Calculated Concentration } \\
\text { in 100 Years } \\
(\mathrm{pCi} / \mathrm{g})\end{array}$ & $\begin{array}{c}\text { EBSL } \\
(\mathrm{pCi} / \mathrm{g})\end{array}$ & $\begin{array}{c}\text { Maximum Concentration } \\
\text { > Screening Values? }\end{array}$ \\
\hline Ag-108m & $6.02 \mathrm{E}-02$ & $1.82 \mathrm{E}+03$ & No \\
C-14 & $4.70 \mathrm{E}-02$ & $3.94 \mathrm{E}+04$ & No \\
Co-60 & $1.92 \mathrm{E}-03$ & $1.18 \mathrm{E}+03$ & No \\
Cs-137 & $6.71 \mathrm{E}+02$ & $4.95 \mathrm{E}+03$ & No \\
Eu-152 & $2.55 \mathrm{E}-03$ & $2.18 \mathrm{E}+03$ & No \\
Eu-154 & $3.26 \mathrm{E}-04$ & $2.48 \mathrm{E}+03$ & No \\
Eu-155 & $1.64 \mathrm{E}-07$ & $3.25 \mathrm{E}+04$ & No \\
H-3 & $1.48 \mathrm{E}-01$ & $3.43 \mathrm{E}+05$ & No \\
I-129 & $2.39 \mathrm{E}-02$ & $4.76 \mathrm{E}+04$ & No \\
Ni-63 & $6.94 \mathrm{E}+01$ & $1.14 \mathrm{E}+05$ & No \\
Np-237 & $2.77 \mathrm{E}-02$ & $1.94 \mathrm{E}+01$ & Yes \\
Pu-239 & $9.18 \mathrm{E}+01$ & $1.89 \mathrm{E}+01$ & No \\
Pu-240 & $1.80 \mathrm{E}+01$ & $1.89 \mathrm{E}+01$ & No \\
Sr-90 & $7.66 \mathrm{E}+02$ & $3.34 \mathrm{E}+03$ & No \\
Tc-99 & $6.24 \mathrm{E}-03$ & $1.60 \mathrm{E}+04$ & No \\
U-233 & $1.16 \mathrm{E}+00$ & $2.05 \mathrm{E}+01$ & No \\
U-234 & $1.18 \mathrm{E}+00$ & $2.05 \mathrm{E}+01$ & No \\
U-235 & $1.45 \mathrm{E}-01$ & $2.27 \mathrm{E}+01$ & No \\
U-238 & $2.95 \mathrm{E}-01$ & $2.32 \mathrm{E}+01$ & \\
\hline a. EBSLs taken from Table A-6 of VanHorn and Stacey $(2004)$. & & \\
\hline
\end{tabular}

\section{IDENTIFICATION OF REMOVAL OBJECTIVES AND SCOPE}

The RAO for this NTCRA is as follows: Reduce risk from external radiation exposure to a total excess cancer risk of less than 1 in 10,000 for a hypothetical resident at 2095 and the current and future worker. Per the OU 1-10 ROD, the TAN area is expected to be under the control of the government until 
2095. In addition, general CERCLA protectiveness standards at INL seek to prevent future releases to the Snake River Plain Aquifer that may result in migration of contaminants to the aquifer such that drinking water maximum contaminant levels may be exceeded and to ensure that cumulative excess cancer risks from multiple contaminants of concern remain less than 1 in 10,000 for a hypothetical resident at 2095 .

The RAO is consistent with those documented in the ROD. The RAO is predicated on the current and future land uses established for the TAN area in the ROD, which include industrial land use until at least 2095 and possible residential land use thereafter. If any newly identified release sites are discovered during implementation of the selected alternative, DOE-ID will consult with DEQ and EPA regarding potential inclusion of the newly identified release sites for evaluation under this EE/CA or the FFA/CO or whether to address the newly identified release sites under other regulatory programs.

\section{IDENTIFICATION OF REMOVAL ACTION ALTERNATIVES}

\subsection{Alternative 1 - No Action Alternative}

The No Action alternative is a hypothetical and conservative, "baseline" established for comparison reasons. The primary assumption is that the sum of identified radiological contamination, if not properly contained or controlled, may be released to the environment causing a potential risk to receptors (current and future workers, hypothetical future residents, and the environment). This assumption is for comparative purposes only and does not reflect the DOE mandate to monitor, maintain, and mitigate potential or actual release from any facility or site to ensure protection to the public and the environment.

\subsection{Alternative 2 - Cold, Dark, and Dry with Continued Surveillance and Monitoring}

Under Alternative 2, the facility will be placed in a cold, dark, and dry condition. Utilities will be disconnected and remaining liquids will be removed prior to placing the building into long-term surveillance and monitoring. Long-term surveillance and monitoring would continue until the building is finally decommissioned in 2095. At the end of the DOE institutional control period, the TAN-607 Hot Shop Area will be decommissioned. The year 2095 is used as the basis for the period of continued surveillance and monitoring as that timeframe is established in the OU 1-10 ROD for TAN (DOE-ID 1999). The OU 1-10 ROD includes industrial land use until at least 2095 and the potential for residential land use thereafter. Implementation of Alternative 2 will delay the start of decommissioning and will require expenditures for continued surveillance and monitoring until final decommissioning. The cost analysis, which is addressed in Section 5.3 of this EE/CA, evaluates the period of surveillance and monitoring through 2095 and the final demolition of TAN-607 in 2095 (in 2006 dollars).

\subsection{Alternative 3 - Demolition, Removal, and Disposal of Building and Building Contents to Meet the Remedial Action Objectives}

The scope of Alternative 3 will include any deactivation or decontamination activities not performed under the Engineering Evaluation/Cost Analysis (EE/CA) for General Decommissioning Activities under the Idaho Cleanup Project (DOE-ID 2006b). Alternative 3 consists of demolishing the TAN-607 aboveground structures and components, removing belowground noninert components, and removing the radiologically contaminated portions of the hot shop, hot cell, and the empty storage pool and vestibule that do not meet the RAOs (shown in blue in Figure 4). Radiologically contaminated debris that meet the RAOs, as defined in the Record of Decision Amendment for the V-Tanks (TSF-09 and TSF-18) and Explanation of Significant Differences for the PM-2A Tanks (TSF-26) and TSF-06, Area 10, 
at Test Area North, Operable Unit 1-10 (DOE-ID 2004), will be left in the excavation created from demolition of TAN-607 and the adjacent void remaining after completion of the V-Tanks soil removal project (shown in red in Figure 4). If radiologically contaminated debris does not meet the RAOs, it will be disposed of in the ICDF subject to meeting the WAC. Nonradiologically contaminated and nonhazardous waste will be disposed of at the TAN Demolition Landfill subject to meeting the WAC.
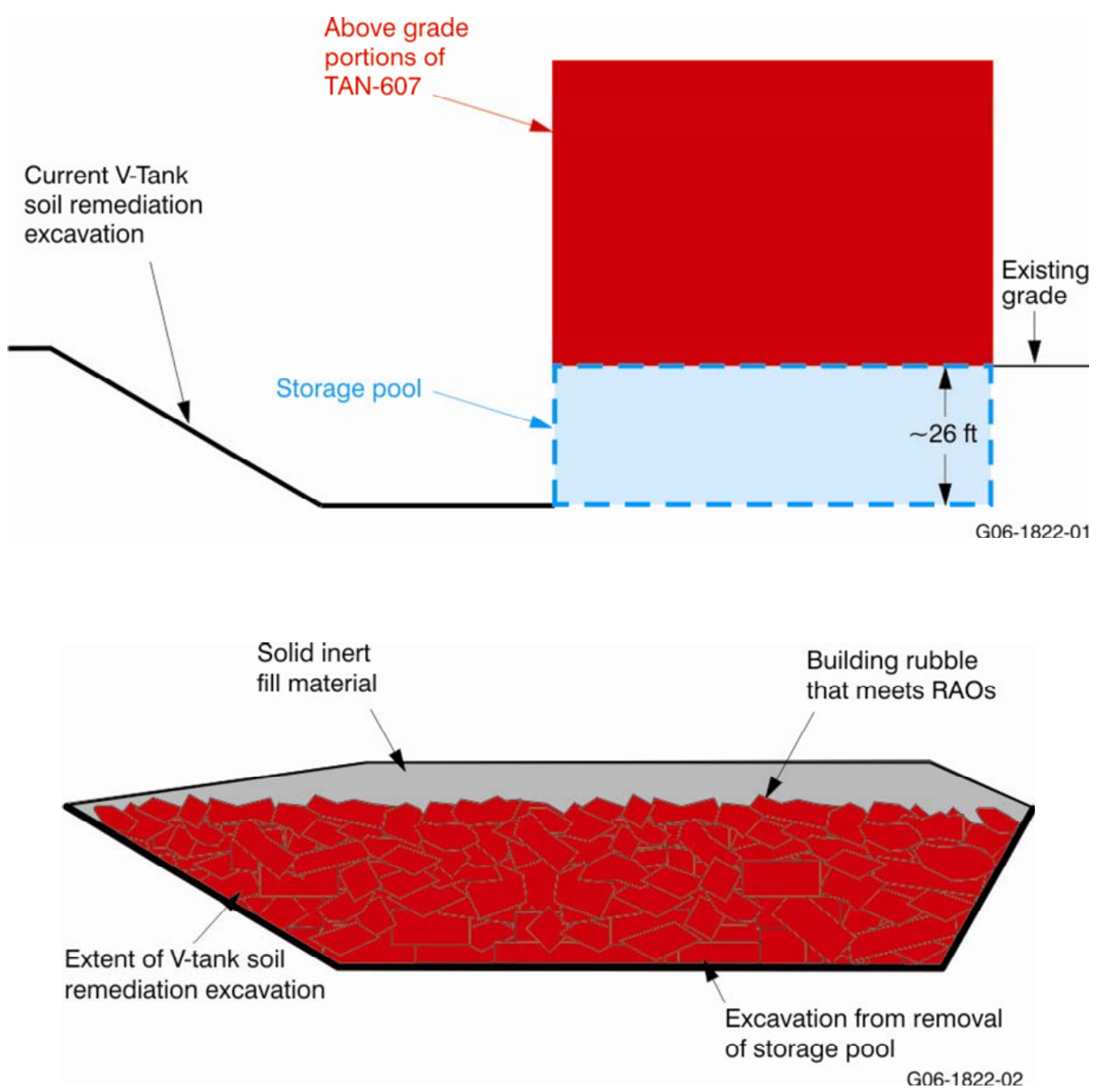

Figure 4. End state of TAN-607.

If waste does not meet the TAN Demolition Landfill or ICDF WAC, a suitable off-Site disposal location will be determined. Upon completion of demolition, the remaining void will be backfilled to grade with solid inert material, graded to meet the natural contour of the area and reseeded. If any newly identified release site(s) are discovered, DOE-ID will consult with DEQ and EPA regarding remediation under this $\mathrm{EE} / \mathrm{CA}$; or, if the extent of contamination is beyond the footprint to be addressed under this EE/CA, the site(s) will be addressed under the FFA/CO or other regulatory programs. 


\section{ALTERNATIVE ANALYSIS}

In accordance with the Guidance on Conducting Non-Time Critical Removal Actions Under CERCLA (EPA 1993), each alternative is evaluated with respect to effectiveness, implementability, and cost.

Effectiveness is evaluated in terms of overall protectiveness of public health and the environment and ability to achieve non-time-critical RAOs. Protectiveness of public health and the environment is evaluated in terms of protection of public health and the community, protection of workers during implementation, protection of the environment, and compliance with applicable or relevant and appropriate requirements (ARARs). (ARARs are also discussed in Section 6.1.) Ability to achieve removal objectives is evaluated in terms of expected level of containment, residual effects, and ability to maintain long-term control.

Implementability of alternatives is evaluated based upon the following: technical feasibility, availability, and administrative feasibility. Technical feasibility is evaluated in terms of construction and operational considerations, demonstrated performance/useful life, adaptability to environmental conditions, contribution to remedial performance, and ability to be implemented in 1 year. Availability is evaluated in terms of equipment, personnel and services, outside laboratory testing capacity, off-Site treatment and disposal capacity, and post-removal site control. Administrative feasibility is evaluated in terms of permits required, easements or rights-of-way required, impact on adjoining property, ability to impose institutional controls, and likelihood of obtaining exemptions from statutory limitations, if needed. Cost of the alternatives is evaluated by considering capital costs, cost for post-removal control (e.g., continued surveillance and maintenance under Alternative 2), and present-worth cost.

On September 30, 2005, Battelle Energy Alliance, LLC, developed PLN-1957, "Infrastructure Transformation Plan," that contains a time phase list of buildings that are surplus and to be dispositioned by 2015 . This plan also includes the current TAN buildings, including the TAN-607 Hot Shop Area, that are not owned by the U.S. Department of Energy Office of Nuclear Energy, Science, and Technology (DOE-NE). DOE-ID has explored several potential missions for the TAN-607 Hot Shop Area facility through marketing initiatives with DOE Headquarters Programs, all without success. PLN-1957 concludes that no new uses, construction, or modifications are planned at TAN.

\subsection{Effectiveness of the Alternatives}

\subsubsection{Protectiveness of Public Health and the Environment}

Protectiveness of public health and the environment is evaluated in terms of protection of public health and the community, protection of workers during implementation, protection of the environment, and compliance with ARARs.

5.1.1.1 Protection of Public Health and the Community. Alternative 1 is the least protective of public health and the community. DOE-ID cannot implement Alternative 1 because it will put workers and the public at risk and will not meet the requirements of federal orders and state and federal laws. Of the three alternatives, Alternative 3 will be most protective of public health and the community as contaminants above the RAOs will be removed and dispositioned appropriately. Actions associated with Alternative 2 will require continued surveillance and maintenance to ensure protection. 
5.1.1.2 Protection of Workers. Protection of workers during implementation varies to some degree between the alternatives. Minimal worker exposure would be expected for Alternative 1. Current INL workers will be exposed to industrial hazards and hazardous materials during actions associated with implementation of Alternative 3. Current workers will not be exposed to the same level of hazards during the continued surveillance and monitoring implemented under Alternative 2. However, worker hazards will be expected in the future when the TAN-607 Hot Shop Area is demolished due to structural degradation of the Hot Shop (it will be at least 150 years old at this time). In addition to the increased industrial hazards encountered by working on a degraded facility under Alternative 2, the remaining radiological contamination (approximately $10 \mathrm{Ci}$ ) would have a more direct pathway to workers.

Alternatives 2 and 3 will both eventually expose the work force to some of the following hazards:

- $\quad$ Excavations - risk of cave-ins/inundation by soils

- Unintentional contact with heavy equipment

- $\quad$ Falling from heights

- $\quad$ Material handling

- Hoisting and rigging

- Use of heavy equipment

- $\quad$ Cutting and grinding

- $\quad$ Radioactive contamination

- Hazardous materials

- $\quad$ Radiation exposure.

The Idaho Cleanup Project (ICP) uses an Integrated Safety Management System that identifies the hazards and plans the controls that will be used to accomplish the task. Only trained workers are used to perform the work, and the ICP actively incorporates lessons learned from around the DOE complex, as well as commercial industry, to plan and perform the work. All work that may expose personnel to radiation is well-planned and exposure goals are set to keep exposure to a minimum. Oversight from Safety and Health personnel occurs for all jobs on a daily basis. The ICP uses a method called a "Step-Back" if conditions occur that are not expected. During a Step-Back, the work is placed in a safe condition and the crew, along with subject matter experts (for example, Radiological Control, Environmental, Engineering, Industrial Hygiene, Deactivation and Decommissioning management), review the existing conditions and develop a strategy that will safely deal with the conditions while minimizing the risk to the workers.

In summary, both Alternatives 2 and 3 will expose the work force to the same types of hazards, but the hazards presented in Alternative 2 will be greater in nature due to the deterioration and decay of the facility over time.

5.1.1.3 Protection of the Environment. Alternative 1 provides the greatest risk to the environment since it assumes no action. If not properly contained or controlled now or in the future, the radiological contamination in TAN-607 may be released to the environment causing a potential risk to receptors. Maximum protection of the environment will be accomplished via implementation of Alternative 3 based on the removal and disposition of contaminants. Under Alternative 2, protection of the environment will be provided to a lesser degree and will be accomplished by long-term surveillance and monitoring and eventually by demolition after the year 2095. 
5.1.1.4 Compliance with ARARs. Section 121 of CERCLA (42 USC $\S 9621$ ) requires the responsible CERCLA implementing agency to ensure that the substantive standards of HWMA/RCRA and other applicable laws will be incorporated into the federal agency's immediate removal actions. DOE-ID is the implementing agency for this NTCRA. Compliance with ARARs will be accomplished for every alternative, as appropriate.

\subsubsection{Ability to Achieve Non-Time-Critical Removal Action Objectives}

Ability to achieve RAOs is evaluated in terms of expected level of containment, residual effects, and ability to maintain long-term control. Alternative 1 provides the greatest potential for release of contaminants, increases residual effects, and decreases the ability to maintain long-term control. Under the Alternative 3 scenario, the entirety of the TAN-607 Hot Shop Area will be removed and dispositioned to the TAN Demolition Landfill, the ICDF landfill, the CFA Landfill, or an appropriate non-INL disposal facility; or, alternately, radiologically contaminated debris that meets RAOs may be used as fill material for the void created by the storage pool and storage pool vestibule walls and floor removal. Under the Alternative 3 scenario, there will be no residual effect concerns regarding waste management, and disposal and control will be maintained without the need to seek an alternative long-term solution. Implementation of Alternative 2 will consist of disconnecting utilities and the removal of remaining liquids prior to placing the building into long-term surveillance and monitoring. The expected level of containment will diminish as the TAN-607 Hot Shop Area structure ages and degrades and applicable RAOs would be met at the time of future decomissioning.

\subsection{Implementability of the Alternatives}

Implementability of alternatives is evaluated based upon the following:

- $\quad$ Technical feasibility

- Technical feasibility is evaluated in terms of construction and operational considerations, demonstrated performance/useful life, adaptability to environmental conditions, contribution to remedial performance, and ability to be implemented in 1 year.

- $\quad$ Availability

- $\quad$ Availability is evaluated in terms of equipment, personnel and services, outside laboratory testing capacity, off-Site treatment and disposal capacity, and post-removal site control.

- Administrative feasibility

- $\quad$ Administrative feasibility is evaluated in terms of permits required, easements or rights-of-way required, impact on adjoining property, ability to impose institutional controls, and likelihood of obtaining exemptions from statutory limitations, if needed.

Alternative 1 is a hypothetical and conservative "baseline" assumption for comparative purposes only. This alternative is not technically feasible since it does not reflect the Agencies' ongoing agreement to identify, assess, and mitigate actual or potential chemical or radiological releases to the public or the environment from any facility or site that is regulated under the CERCLA NTCRA process. In addition, Alternative 1 does not meet the ARARs and will not be evaluated further for technical or administrative feasibility or availability. 


\subsubsection{Technical Feasibility}

Alternative 3 will require an intensive demolition effort to remove structures and components as detailed in Section 4. The deepest excavation will be a minimum of $26 \mathrm{ft}$ below grade. This deepest excavation is associated with removal of the storage pool walls and floor. To meet Occupational Safety and Health Administration requirements for excavations, the excavation must be 1.5 times as wide as it is deep. Under Alternative 3, radiologically contaminated structures and components will be decontaminated, if feasible, and disposed of at the TAN Demolition Landfill. Radiologically contaminated debris that meet RAOs as defined in the Record of Decision Amendment for the $V$-Tanks (TSF-09 and TSF-18) and Explanation of Significant Differences for the PM-2A Tanks (TSF-26) and TSF-06, Area 10, at Test Area North, Operable Unit 1-10 (DOE-ID 2004) will be left in the excavation created from demolition and the adjacent void remaining after completion of the V-Tanks soil removal project. The debris and components that are removed, as detailed in Section 4, will be disposed of at ICDF or the TAN Demolition Landfill. Implementation of Alternative 3 is anticipated to take about 1 year. Implementation is technically feasible. In the near term, implementation of Alternative 3 will be at an increased cost in terms of time, materials, transportation, exposure to industrial hazards, and services compared to Alternative 2 .

Alternative 2 will require minimal immediate expenditure of time, resources, engineering, or development to place the facility into a cold, dark, and dry state. However, continued surveillance, monitoring, and maintenance will require an expenditure of resources through the year 2095. The primary deterrent to the implementation of this alternative will be the potential radiation exposure of workers and the environment and the hazards of entering an aging facility. Therefore, although implementation of Alternative 2 will be technically feasible, a potential threat to worker health and the environment will remain.

\subsubsection{Availability}

Availability of equipment, personnel and services, outside laboratory testing capacity, off-Site treatment and disposal capacity, and post-removal site control will not impose any limitations on either Alternative 2 or 3 . The resources required to implement both of the alternatives will be available.

\subsubsection{Administrative Feasibility}

No permit requirements, easement or rights-of-way requirements, impacts on adjoining property, or exemptions from statutory limitations will be associated with Alternative 2 or 3 . Institutional controls would be required for Alternatives 2 and 3 but the ability to implement those institutional controls would not be impacted.

\subsection{Cost of the Alternatives}

The cost of the alternatives is based on detailed cost estimates (see Table 5). These estimates do not include general and administrative costs and are based on 2006 dollars with no escalation. These estimates include direct costs such as labor, fringe, materials, equipment, supplies, and subcontracts. Alternative 1 will not eliminate, reduce, or control potential risks to human health and the environment. DOE-ID is required by federal orders and state and federal laws to protect workers and the public from unacceptable exposures. The INL currently has administrative and physical controls in place to prevent unacceptable exposures to ionizing radiation and other chemical hazards from contaminated materials. DOE-ID cannot implement a "No Action alternative" (i.e., no administrative or physical controls) because it will put workers and the public at risk and will not meet the requirements of federal orders and state and 
federal laws. Alternative 1, the No Action alternative, cannot be considered a viable alternative and, as such, a cost estimate has not been prepared.

Table 5. Cost estimates for alternatives.

\begin{tabular}{lcc}
\hline \multicolumn{1}{c}{ Cost Description } & Alternative 2 & Alternative 3 \\
\hline TAN-607 Deactivation and/or Decommissioning & $\$ 1,476,979$ & $\$ 33,724,553$ \\
$\begin{array}{l}\text { Continued Surveillance and Monitoring Until 2095 } \\
\text { (quarterly) }\end{array}$ & $\$ 9,052,032$ & Not applicable \\
$\begin{array}{l}\text { Final Demolition of TAN-607 Post-2095 } \\
\text { (2006 dollars) }\end{array}$ & $\$ 32,247,574$ & Not applicable \\
Total & $\$ 42,776,585$ & $\$ 33,724,553$ \\
\hline
\end{tabular}

The cost estimates cited in Table 5 are based upon performing the work associated with the proposed actions over the next calendar year, until 2095, and post-2095. The cost estimate cited for Alternative 2 assumes that the facility will be maintained in a cold, dark, and dry configuration and condition through at least Fiscal Year 2095 and that demolition will not begin till at least 2095.

\subsection{Evaluation Summary}

This section provides a summary of the effectiveness of the alternatives.

- $\quad$ Alternative 1 provides the greatest risk to the environment since it assumes no action. If not properly contained or controlled now or in the future, the radiological contamination in TAN-607 may be released to the environment causing a potential risk to receptors. Alternative 1 is a hypothetical and conservative "baseline" assumption for comparative purposes only and does not reflect the Agencies' ongoing agreement to identify, assess, and mitigate actual or potential releases to the public or the environment from any facility or site that is regulated under the CERCLA NTCRA process. Until decommissioning commences, contaminated facilities or sites will be monitored, maintained, and contained/controlled by DOE-ID as necessary to prevent and/or mitigate potential releases. Therefore, Alternative 1 is not considered a viable alternative.

- $\quad$ Actions associated with Alternative 3 are most protective of public health and the community as contaminants will be removed and dispositioned appropriately.

- Implementation of Alternative 3 will pose the most risk to the worker in the short term. However, under Alternative 2, as the building deteriorates, the risk posed to workers in the future will be substantially greater during surveillance, monitoring, maintenance, and ultimate demolition.

- Maximum protection of the environment will be accomplished by implementation of Alternative 3 based on removal and disposition of contaminants. Under Alternative 2, protection of the environment will be provided to a lesser degree but will be accomplished by long-term surveillance, monitoring, and maintenance.

- $\quad$ ARARs will be met under Alternative 2 and Alternative 3.

- $\quad$ Alternative 3 achieves non-time-critical removal objectives by removal of the current risk posed by the residual contaminants. 
- $\quad$ The implementation of both Alternatives 2 and 3 is technically feasible. Alternative 3 will take about 1 year to complete. The resources required to implement each of the alternatives are available and both are administratively feasible, although the ultimate demolition of the TAN-607 Hot Shop Area structure will not be initiated until the year 2095 under the Alternative 2 scenario.

- A comparison of the costs associated with each alternative shows that Alternative 3 will be the least costly alternative to implement, and Alternative 3 eliminates the risks by completing the full demolition and remediation of the CERCLA sites in the near term. The cost estimate for Alternative 2 includes facility monitoring and surveillance through 2095 and the ultimate demolition of the facility post-2095.

\section{RECOMMENDED ALTERNATIVE}

An evaluation of the alternatives in terms of effectiveness, implementability, and cost shows that Alternative 3 is the preferred alternative. As discussed above, if no action is taken there will be an unacceptable risk. Implementation of Alternative 3 will ensure protection of human health and the environment by achieving an end state that provides the lowest risk and cost with the fewest post-closure activities. It also eliminates unnecessary infrastructure and overhead costs and reduces the Environmental Management footprint liability. Alternative 3 will meet the RAOs as defined in the Record of Decision Amendment for the V-Tanks (TSF-09 and TSF-18) and Explanation of Significant Differences for the PM$2 A$ Tanks (TSF-26) and TSF-06, Area 10, at Test Area North, Operable Unit 1-10 (DOE-ID 2004). Alternative 3 supports the DOE-ID long-term mission for risk reduction and building footprint reduction.

The following sections identify the requirements that will be met during the implementation of this NTCRA.

\subsection{Compliance with Environmental Regulations, Including Those That Are Applicable or Relevant and Appropriate Requirements}

\subsubsection{CERCLA}

Section 121 of CERCLA (42 USC § 9621) requires the responsible CERCLA implementing agency ensure that the substantive standards of HWMA/RCRA and other applicable laws will be incorporated into the federal agency's design and operation of its long-term remedial actions and into its more immediate removal actions. DOE-ID is the implementing agency for this NTCRA. EPA and DEQ will review this EE/CA and will concur, if appropriate, in the Action Memorandum.

Implementation of Alternative 3 will result in the generation and subsequent management of radioactive and nonradioactive wastes. Table 6 lists the proposed ARARs that are identified for this alternative. These ARARs are a compilation and expansion of the ARARs identified in the OU 1-10 ROD (DOE-ID 1999). The ARARs list is based on the following key assumptions:

- $\quad$ CERCLA waste generated during the removal action will be disposed of at the ICDF landfill and the TAN Demolition Landfill subject to meeting the WAC.

- If decontamination liquids are generated, they will be disposed of at the ICDF evaporation ponds subject to meeting the WAC. 
Table 6. Summary of ARARs for the TAN-607 Hot Shop Area, non-time-critical removal action.

\begin{tabular}{|c|c|c|}
\hline $\begin{array}{l}\text { Requirement } \\
\text { (Citation) }\end{array}$ & $\begin{array}{l}\text { ARAR } \\
\text { Type }\end{array}$ & Comments \\
\hline \multicolumn{3}{|l|}{ Clean Air Act and Idaho Air Regulations } \\
\hline “Toxic Substances,” IDAPA 58.01.01.161 & A & Applies to any toxic substances emitting during implementation of the removal action. \\
\hline $\begin{array}{l}\text { "National Emission Standards for Hazardous Air Pollutants," } \\
<10 \text { mrem/yr, } 40 \text { CFR } 61.92 \text {,"Standard" }\end{array}$ & A & Applies to building demolition and the waste-handling activities. \\
\hline $\begin{array}{l}\text { "National Emission Standards for Hazardous Air Pollutants," } \\
\text { "Emission Monitoring and Test Procedures," 40 CFR 61.93 }\end{array}$ & A & Applies to building demolition and the waste-handling activities. \\
\hline $\begin{array}{l}\text { "National Emission Standards for Hazardous Air Pollutants," } \\
\text { "Compliance and Reporting," } 40 \text { CFR 61.94(a) }\end{array}$ & A & Applies to building demolition and the waste-handling activities. \\
\hline $\begin{array}{l}\text { "National Emission Standards for Hazardous Air Pollutants," } \\
\text { "Standards for Demolition and Renovation," 40 CFR 61.145 }\end{array}$ & A & Applies to any asbestos-containing materials removed during the decommissioning. \\
\hline $\begin{array}{l}\text { "Rules for Control of Fugitive Dust," and "General Rules," } \\
\text { IDAPA 58.01.01.650 and .651 }\end{array}$ & A & Applies to building demolition and the waste-handling activities. \\
\hline \multicolumn{3}{|l|}{ RCRA and Idaho Hazardous Waste Management Act } \\
\hline \multicolumn{3}{|c|}{ "Standards Applicable to Generators of Hazardous Waste," IDAPA 58.01.05.006, and the following, as cited in it: } \\
\hline "Hazardous Waste Determination," 40 CFR 262.11 & A & Applies to waste generated during the removal action. \\
\hline \multicolumn{3}{|l|}{ General Facility Standards } \\
\hline \multicolumn{3}{|c|}{ "Standards for Owners and Operators of Hazardous Waste Treatment, Storage, and Disposal Facilities," IDAPA 58.01.05.008, and the following, as cited in it:. } \\
\hline “Temporary Units (TU),” 40 CFR 264.553 & A & Waste may be treated or temporarily stored in a temporary unit prior to disposal. \\
\hline “Staging Piles,” 40 CFR 264.554 & A & Waste may be temporarily staged prior to disposal. \\
\hline “General Inspections Requirements,” 40 CFR 264.15 & A & $\begin{array}{l}\text { Applies to a facility staging, storing, or treating hazardous waste prior to transfer to the } \\
\text { ICDF or an off-Site facility. }\end{array}$ \\
\hline "Preparedness and Prevention," 40 CFR 264, Subpart C & A & $\begin{array}{l}\text { Applies to a facility staging, storing, or treating hazardous waste prior to transfer to the } \\
\text { ICDF or an off-Site facility. }\end{array}$ \\
\hline $\begin{array}{l}\text { "Contingency Plan and Emergency Procedures," } 40 \text { CFR 264, } \\
\text { Subpart D }\end{array}$ & A & $\begin{array}{l}\text { Applies to a facility staging, storing, or treating hazardous waste prior to transfer to the } \\
\text { ICDF or an off-Site facility. }\end{array}$ \\
\hline $\begin{array}{l}\text { "Disposal or Decontamination of Equipment, Structures, and } \\
\text { Soils," } 40 \text { CFR } 264.114\end{array}$ & A & $\begin{array}{l}\text { Applies to contaminated equipment used to remove, treat, or transport hazardous } \\
\text { waste. }\end{array}$ \\
\hline "Use and Management of Containers," 40 CFR 264.171-178 & A & Applies to containers used during the removal and treatment of hazardous waste. \\
\hline
\end{tabular}


Table 6. (continued).

\begin{tabular}{|c|c|c|}
\hline $\begin{array}{l}\text { Requirement } \\
\text { (Citation) }\end{array}$ & $\begin{array}{l}\text { ARAR } \\
\text { Type }\end{array}$ & Comments \\
\hline \multicolumn{3}{|l|}{ Land Disposal Restrictions } \\
\hline \multicolumn{3}{|c|}{ "Land Disposal Restrictions," IDAPA 58.01.05.011, and the following, as cited in it: } \\
\hline “Applicability of Treatment Standards," 40 CFR 268.40(a)(b)(e) & A & $\begin{array}{l}\text { Applies to hazardous waste and secondary waste, if treatment is necessary to meet the } \\
\text { disposal facility's WAC or if treatment is required before placement. }\end{array}$ \\
\hline "Treatment Standards for Hazardous Debris," 40 CFR 268.45 & A & $\begin{array}{l}\text { Applies to hazardous debris, if treatment is necessary to meet the disposal facility's } \\
\text { WAC or if treatment is required before placement. }\end{array}$ \\
\hline "Universal Treatment Standards," 40 CFR 268.48(a) & A & $\begin{array}{l}\text { Applies to nondebris hazardous waste and secondary waste, if treatment is necessary } \\
\text { to meet the disposal facility's WAC or if treatment is required before placement. }\end{array}$ \\
\hline $\begin{array}{l}\text { "Alternative LDR Treatment Standards for Contaminated Soil," } \\
40 \text { CFR 268.49 }\end{array}$ & A & $\begin{array}{l}\text { Applies to contaminated soil, if treatment is necessary to meet the disposal facility's } \\
\text { WAC or if treatment is required before placement. }\end{array}$ \\
\hline \multicolumn{3}{|l|}{ Idaho Groundwater Quality Rules } \\
\hline “Ground Water Quality Rule,” IDAPA 58.01.011 & A & $\begin{array}{l}\text { The waste-handling activities shall prevent migration of contaminants from the facility } \\
\text { that will cause the Snake River Plain Aquifer groundwater to exceed applicable State } \\
\text { of Idaho groundwater quality standards in } 2095 \text { and beyond. The State of Idaho } \\
\text { Ground Water Quality Rule's regulated levels of contaminants are equivalent to the } \\
\text { Clean Water Act maximum contaminant levels. }\end{array}$ \\
\hline \multicolumn{3}{|l|}{ TSCA } \\
\hline $\begin{array}{l}\text { "Decontamination Standards and Procedures: Decontamination } \\
\text { Standards," } 40 \text { CFR } 761.79(\mathrm{~b})(1)\end{array}$ & A & $\begin{array}{l}\text { Applicable to decontamination of equipment with PCB contamination, if PCB waste is } \\
\text { generated. }\end{array}$ \\
\hline $\begin{array}{l}\text { "Decontamination Standards and Procedures: Self-Implementing } \\
\text { Decontamination Procedures," } 40 \text { CFR 761.79(c)(1) and (2) }\end{array}$ & A & $\begin{array}{l}\text { Applicable to decontamination of equipment with PCB contamination, if PCB waste is } \\
\text { generated. }\end{array}$ \\
\hline "Disposal in Solid Waste Landfills," 40 CFR 761.62(b) & A & $\begin{array}{l}\text { Applicable to disposition of waste in a NMSWLF with concentrations of PCBs greater } \\
\text { than } 50 \mathrm{ppm} \text {. }\end{array}$ \\
\hline $\begin{array}{l}\text { "Decontamination Standards and Procedures: Decontamination } \\
\text { Solvents," } 40 \text { CFR } 761.79(\mathrm{~d})\end{array}$ & A & $\begin{array}{l}\text { Applicable to decontamination of equipment used to manage PCB-contaminated } \\
\text { waste, if PCB waste is generated. }\end{array}$ \\
\hline $\begin{array}{l}\text { "Decontamination Standards and Procedures: Limitation of Exposure } \\
\text { and Control of Releases," } 40 \text { CFR 761.79(e) }\end{array}$ & A & $\begin{array}{l}\text { Applicable to decontamination activities of equipment with PCB-contaminated waste, } \\
\text { if decontamination is performed. }\end{array}$ \\
\hline $\begin{array}{l}\text { "Decontamination Standards and Procedures: Decontamination Waste } \\
\text { and Residues," } 40 \text { CFR } 761.79(\mathrm{~g})\end{array}$ & A & $\begin{array}{l}\text { Applicable to management of decontaminated waste and residuals from } \\
\text { PCB-contaminated equipment, if PCB waste is generated. }\end{array}$ \\
\hline
\end{tabular}


Table 6. (continued).

\begin{tabular}{|c|c|c|}
\hline $\begin{array}{l}\text { Requirement } \\
\text { (Citation) }\end{array}$ & $\begin{array}{l}\text { ARAR } \\
\text { Type }\end{array}$ & Comments \\
\hline \multicolumn{3}{|l|}{ Solid Waste Management Rules } \\
\hline $\begin{array}{l}\text { IDAPA 58.01.06.012, Solid Waste Management Rules for Tier II } \\
\text { Landfills }\end{array}$ & A & Applicable to operation and management of TAN Demolition Landfill. \\
\hline \multicolumn{3}{|l|}{ To-be-Considered Requirements } \\
\hline $\begin{array}{l}\text { "Radiation Protection of the Public and the Environment," } \\
\text { DOE Order } 5400.5 \text {, Chapter } \operatorname{II}(1)(a, b)\end{array}$ & $\mathrm{TBC}$ & $\begin{array}{l}\text { Applies. Substantive design and construction requirements will be met to keep public } \\
\text { exposures as low as reasonably achievable. }\end{array}$ \\
\hline $\begin{array}{l}\text { Region } 10 \text { Final Policy on the Use of Institutional Controls at Federal } \\
\text { Facilities, May } 2006 \text { (EPA 2006) }\end{array}$ & $\mathrm{TBC}$ & Applies to residual waste following completion of the removal action. \\
\hline $\begin{array}{l}\mathrm{A}=\text { applicable requirement. } \\
\mathrm{ARAR}=\text { applicable or relevant and appropriate requirement. } \\
\mathrm{CFR}=\text { Code of Federal Regulations. } \\
\text { DOE = U.S. Department of Energy. } \\
\text { EPA = U.S. Environmental Protection Agency. } \\
\text { ICDF = Idaho CERCLA Disposal Facility. } \\
\text { IDAPA = Idaho Administrative Procedures Act. }\end{array}$ & & $\begin{array}{l}\text { NMSWLF = Non-Municipal Solid Waste Landfill. } \\
\text { PCB = polychlorinated biphenyl. } \\
\text { RCRA = Resource Conservation and Recovery Act. } \\
\text { TAN = Test Area North. } \\
\text { TBC }=\text { to be considered. } \\
\text { TSCA = Toxic Substances Control Act. } \\
\text { WAC = Waste Acceptance Criteria. }\end{array}$ \\
\hline
\end{tabular}


- Debris generated during demolition of the TAN-607 Hot Shop Area may contain paint contaminated with PCBs. If encountered, such wastes may trigger the substantive requirements of TSCA. Lead-contaminated paint may be generated during demolition, which will be subject to the substantive requirements of RCRA. These wastes will be disposed of at either the ICDF landfill or TAN Demolition Landfill if eligible for disposal as solid waste.

- $\quad$ Asbestos-containing material may be encountered incidental to performance of the NTCRA. Nonradiological contaminated regulated asbestos-containing material (RACM) encountered during the TAN-607 Hot Shop Area decommissioning will be appropriately removed and disposed of in the CFA Asbestos Landfill. Only waste that meets the requirements of IDAPA 58.01.06.012, "Applicable Requirements for Tier II Facilities," will be disposed of in the TAN Demolition Landfill. Radiological contaminated asbestos will be disposed of at the ICDF per those WAC requirements.

A summary of ARARs for the TAN-607 Hot Shop Area is found in Table 6 .

\subsubsection{Cultural Resources}

Section 106 of the National Historic Preservation Act of 1966 (16 USC $\S 470$ et seq.), as amended, requires agencies to consider the impact of undertakings on properties listed or eligible for listing in the National Register of Historic Places and to consult with the Idaho State Historic Preservation Office (SHPO) and other interested parties when impacts are likely. It also requires federal agencies to invite the Advisory Council on Historic Preservation (ACHP) to participate in consultation, when impacts may be adverse. The Section 106 process is tailored to meet the unique needs of the INL and is described in the INL Cultural Resource Management Plan (DOE-ID 2005a).

TAN-607 proper (including TAN-607A and the TAN-607 Hot Shop Area) is a historic property eligible for nomination to the National Register of Historic Places. TAN-607 property is designated as a Signature Property by DOE Headquarters. DOE-ID decided to proceed with demolition of TAN-607 proper. As a Signature Property, public review of facility disposition is required. To mitigate adverse impacts caused by such action, DOE-ID, through formal consultation with the Idaho SHPO, developed a Memorandum of Agreement (MOA) (DOE-ID 2005b) outlining measures to preserve the TAN-607 proper history, as well as commitments to edit and republish a public history book on the INL, publish and distribute historical reports written for inclusion in Library of Congress collections, endow a university scholarship for students pursuing a degree in a preservation-related discipline, and preserve technical reports, engineering drawings, historic photographs, and other important documents in an INL archive through the support of a professional archivist. DOE-ID invited ACHP to participate in consultation and to be a signatory to the MOA. The ACHP declined to participate. The MOA, signed by DOE-ID and the Idaho SHPO in October 2005, outlines a schedule for completion of each stipulated mitigation measure.

DOE-ID is required to review as guidance the most current U.S. Fish and Wildlife Service list for threatened and endangered plant and animal species. DOE-ID determined that none of the alternatives will impact any threatened and endangered species and also determined that formal consultation with the U.S. Fish and Wildlife Service is not required for this action. 


\subsection{Compliance with Non-INL Disposal Facility Waste Acceptance Criteria}

Waste disposal facilities available at the INL are expected to be able to accommodate the waste generated during this removal action. Waste generated during decommissioning activities associated with implementation of the selected alternative is anticipated to meet the WAC for either the TAN Demolition Landfill or ICDF landfill. Any waste generated that does not meet the WAC of these INL facilities will be staged for disposal at an off-Site facility, subject to meeting its WAC.

\subsection{TAN Demolition Landfill Waste Acceptance Criteria}

Construction and demolition debris with painted or treated surfaces may be accepted at the TAN Demolition Landfill so long as the debris does not qualify as a hazardous waste pursuant to RCRA and does comply with the state and federal disposal requirements for PCBs as identified in TSCA. The following types of nonhazardous and nonradioactive construction and demolition waste may be taken to the TAN Demolition Landfill for disposal: asphalt, concrete, masonry block, brick, flooring material, gypsum board, scrap metal, steel roofing, steel siding, insulated siding, gravel, rock, building lumber, wiring, soil, inert waste, and nonfriable asbestos-containing material. RACM will be removed and disposed of at the CFA Asbestos Landfill during the deactivation of the TAN-607 Hot Shop Area under an existing National Environmental Policy Act action. Any RACM encountered during the TAN-607 Hot Shop Area decommissioning will be appropriately removed and disposed of in the CFA Asbestos Landfill. Only waste that meets the requirements of IDAPA 58.01.06.012, "Applicable Requirements for Tier II Facilities," will be disposed of in the TAN Demolition Landfill.

\subsection{Idaho CERCLA Disposal Facility Waste Acceptance Criteria}

The ICDF landfill will accept only low-level, mixed low-level, hazardous, and TSCA waste generated from INL Site CERCLA activities. The ICDF landfill is one option for disposing of the radioactively contaminated decommissioning waste. Decommissioning waste not requiring treatment to meet land disposal restriction requirements can be sent to the ICDF landfill, if it meets the waste acceptance requirements as outlined in Waste Acceptance Criteria for ICDF Landfill (DOE-ID 2005c). Based on data currently available on the waste that will be generated from the TAN-607 Hot Shop Area decommissioning process, treatment is not expected to be required to meet the land disposal restrictions for the ICDF. Waste considered for disposal at the ICDF includes such items as piping, sump pumps, contaminated portions of the slab, and other pieces of equipment that might be radioactively contaminated and not meet the criteria for the TAN Demolition Landfill.

\section{REFERENCES}

40 CFR 61.92, 2006, "Standard," Code of Federal Regulations, Office of the Federal Register, November 2006.

40 CFR 61.93, 2006, "Emission Monitoring and Test Procedures," Code of Federal Regulations, Office of the Federal Register, November 2006.

40 CFR 61.94, 2006, "Compliance and Reporting," Code of Federal Regulations, Office of the Federal Register, November 2006.

40 CFR 61.145, 2006, "Standard for Demolition and Renovation," Code of Federal Regulations, Office of the Federal Register, November 2006. 
40 CFR 262.11, 2006, "Hazardous Waste Determination," Code of Federal Regulations, Office of the Federal Register, August 2006.

40 CFR 264, Subpart C, 2006, "Preparedness and Prevention," Code of Federal Regulations, Office of the Federal Register, July 2006.

40 CFR 264, Subpart D, 2006, "Contingency Plan and Emergency Procedures," Code of Federal Regulations, Office of the Federal Register, July 2006.

40 CFR 264.15, 2006, "General Inspection Requirements," Code of Federal Regulations, Office of the Federal Register, July 2006.

40 CFR 264.114, 2006, "Disposal or Decontamination of Equipment, Structures and Soils," Code of Federal Regulations, Office of the Federal Register, July 2006.

40 CFR 264.171, 2006, "Condition of Containers," Code of Federal Regulations, Office of the Federal Register, July 2006.

40 CFR 264.172, 2006, "Compatibility of Waste with Containers," Code of Federal Regulations, Office of the Federal Register, July 2006.

40 CFR 264.173, 2006, "Management of Containers," Code of Federal Regulations, Office of the Federal Register, July 2006.

40 CFR 264.174, 2006, "Inspections," Code of Federal Regulations, Office of the Federal Register, July 2006.

40 CFR 264.175, 2006, “Containment," Code of Federal Regulations, Office of the Federal Register, July 2006.

40 CFR 264.176, 2006, "Special Requirements for Ignitable or Reactive Waste," Code of Federal Regulations, Office of the Federal Register, July 2006.

40 CFR 264.177, 2006, "Special Requirements for Incompatible Wastes," Code of Federal Regulations, Office of the Federal Register, July 2006.

40 CFR 264.178, 2006, "Closure," Code of Federal Regulations, Office of the Federal Register, July 2006.

40 CFR 264.553, 2006, “Temporary Units (TU)," Code of Federal Regulations, Office of the Federal Register, July 2006.

40 CFR 264.554, 2006, "Staging Piles," Code of Federal Regulations, Office of the Federal Register, July 2006.

40 CFR 268.40, 2006, "Applicability of Treatment Standards," Code of Federal Regulations, Office of the Federal Register, July 2006.

40 CFR 268.45, 2006, "Treatment Standards for Hazardous Debris," Code of Federal Regulations, Office of the Federal Register, July 2006. 
40 CFR 268.48, 2006, "Universal Treatment Standards," Code of Federal Regulations, Office of the Federal Register, July 2006.

40 CFR 268.49, 2006, “Alternative LDR Treatment Standards for Contaminated Soil," Code of Federal Regulations, Office of the Federal Register, July 2006.

40 CFR 300, 2006, "National Oil and Hazardous Substances Pollution Contingency Plan," Code of Federal Regulations, Office of the Federal Register, November 2006.

40 CFR 761.62(b), 2006, "Disposal in Solid Waste Landfills," Code of Federal Regulations, Office of the Federal Register, June 2006.

40 CFR 761.79(b), 2006, "Decontamination Standards," Code of Federal Regulations, Office of the Federal Register, June 2006.

40 CFR 761.79(c), 2006, "Self-Implementing Decontamination Procedures," Code of Federal Regulations, Office of the Federal Register, June 2006.

40 CFR 761.79(d), 2006, “Decontamination Solvents," Code of Federal Regulations, Office of the Federal Register, June 2006.

40 CFR 761.79(e), 2006, "Limitation of Exposure and Control of Releases," Code of Federal Regulations, Office of the Federal Register, June 2006.

40 CFR 761.79(g), 2006, "Decontamination Waste and Residues," Code of Federal Regulations, Office of the Federal Register, June 2006.

16 USC $\S 470$ et seq., 1966, "National Historic Preservation Act," United States Code, October 15, 1966.

42 USC $\S 9601$ et seq., 1980, “Comprehensive Environmental Response, Compensation and Liability Act of 1980 (CERCLA/Superfund)," United States Code, December 11, 1980.

42 USC § 9621, 1998, “Cleanup Standards,” United States Code, January 26, 1998.

Areva, 2004, "Microshield," Version 6.10, Framatome ANP, Inc., an Areva and Siemens company, 3315 Old Forest Road, Lynchburg, VA 24501.

DOE and EPA, 1995, Policy on Decommissioning of Department of Energy Facilities Under the Comprehensive Environmental Response, Compensation, and Liability Act (CERCLA), KLF-211-95, Rev. 0, U.S. Department of Energy, Washington, D.C., and U.S. Environmental Protection Agency, Washington, D.C., May 22, 1995.

DOE O 5400.5, 1993, Change 2, "Radiation Protection of the Public and the Environment," U.S. Department of Energy, January 7, 1993.

DOE-ID, 1991, Federal Facility Agreement and Consent Order for the Idaho National Engineering Laboratory and Action Plan, Administrative Record No. 1088-06-29-120, U.S. Department of Energy Idaho Operations Office; U.S. Environmental Protection Agency, Region 10; Idaho Department of Health and Welfare. Available online at http://ar.inel.gov/.

DOE-ID, 1994, Track 2 Sites: Guidance for Assessing Low Probability Hazard Sites at the INEL, DOE/ID-10389, Rev. 6, U.S. Department of Energy Idaho Operations Office, January 1994. 
DOE-ID, 1995, Declaration for the Technical Support Facility Injection Well (TSF-05) and Surrounding Groundwater Contamination (TSF-23) and Miscellaneous No Action Sites Final Remedial Action, Operable Unit 1-07B, Waste Area Group 1, Idaho National Engineering Laboratory, Document ID 10139, U.S. Environmental Protection Agency, Idaho Department of Environmental Quality, U.S. Department of Energy Idaho Operations Office, August 1995.

DOE-ID, 1999, Final Record of Decision for Test Area North Operable Unit 1-10 Idaho National Engineering and Environmental Laboratory, Idaho Falls, Idaho, DOE/ID-10682, Rev. 0, U.S. Environmental Protection Agency, Idaho Department of Environmental Quality, U.S. Department of Energy Idaho Operations Office, October 1999.

DOE-ID, 2004, Record of Decision Amendment for the V-Tanks (TSF-09 and TSF-18) and Explanation of Significant Differences for the PM-2A Tanks (TSF-26) and TSF-06, Area 10, at Test Area North, Operable Unit 1-10, DOE/ID-10682, Amend, Rev. 0, U.S. Environmental Protection Agency, Idaho Department of Environmental Quality, U.S. Department of Energy Idaho Operations Office, February 2004.

DOE-ID, 2005a, Idaho National Laboratory Cultural Resource Management Plan, DOE/ID-10997, Rev. 1, U.S. Department of Energy Idaho Operations Office, September 2005.

DOE-ID, 2005b, Memorandum of Agreement Between the United States Department of Energy, Idaho Operations Office, and the Idaho State Historic Preservation Office, DOEID-1394, U.S. Department of Energy Idaho Operations Office, October 27, 2005.

DOE-ID, 2005c, Waste Acceptance Criteria for ICDF Landfill, DOE/ID-10865, Rev. 8, U.S. Department of Energy, Idaho Operations Office, February 2005.

DOE-ID, 2006a, Engineering Evaluation/Cost Analysis (EE/CA) for Decommissioning of TAN-630 and TAN-650 at the Loss-of-Fluid Test (LOFT) Area, DOE/ID-11253, Rev. 0, U.S. Department of Energy Idaho Operations Office, January 2006.

DOE-ID, 2006b, Engineering Evaluation/Cost Analysis (EE/CA) for General Decommissioning Activities under the Idaho Cleanup Project, DOE/ID-11291, Rev 0, U.S. Department of Energy Idaho Operations Office, August 2006.

EDF-7515, 2006, "Groundwater Assessment for TAN-607: Hot Shop Area," Rev. 0, Idaho National Laboratory, Idaho Cleanup Project, December 2006.

EPA, 1993, Guidance on Conducting Non-Time Critical Removal Actions Under CERCLA, EPA/540-R-93-057, U.S. Environmental Protection Agency, August 1993.

EPA, 2006, Region 10 Final Policy on the Use of Institutional Controls at Federal Facilities, U.S. Environmental Protection Agency, May 2006.

ICP, 2006, Engineering Evaluation/Cost Analysis (EE/CA) for Decommissioning of TAN-607A, RPT-214, Idaho National Laboratory, Idaho Cleanup Project, July 2006.

IDAPA 58.01.01.161, 1995, “Toxic Substances,” Idaho Administrative Procedures Act, Idaho Department of Environmental Quality, June 30, 1995. 
IDAPA 58.01.01.650, 1994, "Rules for Control of Fugitive Dust," Idaho Administrative Procedures Act, Idaho Department of Environmental Quality, May 1, 1994.

IDAPA 58.01.01.651, 1994, “General Rules,” Idaho Administrative Procedures Act, Idaho Department of Environmental Quality, May 1, 1994.

IDAPA 58.01.05.006, 2006, "Standards Applicable to Generators of Hazardous Waste," Idaho Administrative Procedures Act, Idaho Department of Environmental Quality, April 11, 2006.

IDAPA 58.01.05.008, 2006, "Standards for Owners and Operators of Hazardous Waste Treatment, Storage, and Disposal Facilities," Idaho Administrative Procedures Act, Idaho Department of Environmental Quality, April 11, 2006.

IDAPA 58.01.05.011, 2006, "Land Disposal Restrictions," Idaho Administrative Procedures Act, Idaho Department of Environmental Quality, April 11, 2006.

IDAPA 58.01.06.012, 2003, “Applicable Requirements for Tier II Facilities,” Idaho Administrative Procedures Act, Idaho Department of Environmental Quality, April 3, 2003.

IDAPA 58.01.011, 1997, “Ground Water Quality Rule,” Idaho Administrative Procedures Act, Idaho Department of Environmental Quality, March 20, 1997.

PLN-1957, 2005, “Infrastructure Transformation Plan,” Rev. 1, Idaho National Laboratory, September 30, 2005. (available via http://ioip.inel.gov/plans/docs/final_plan.pdf)

Public Law 99-499, 1986, "Superfund Amendments and Reauthorization Act of 1986 (SARA)," 100 Statutes 1728, Public Law, October 17, 1986.

Rood, A. S., 2003, GWSCREEN: A Semi-Analytical Model for Assessment of the Groundwater Pathway from Surface or Buried Contamination: Theory and User's Manual Version 2.5, INEEL/EXT-98-00750, Rev. 1b, Idaho National Engineering and Environmental Laboratory April 2003.

VanHorn, R., and Stacey, S., 2004, Risk-Based Screening and Assessment Approach for Waste Area Group 1 Soils, INEEL/EXT-03-00540, Rev. 0, Idaho National Engineering and Environmental Laboratory, Idaho Completion Project, May 2004. 